\title{
Woody plant secondary chemicals increase in response to abundant deer and arrival of invasive plants in suburban forests
}

\author{
Janet A. Morrison ${ }^{1}$, Bernadettte Roche ${ }^{2}$, and Maren Veatch-Blohm ${ }^{3}$ \\ ${ }^{1}$ Department of Biology, The College of New Jersey, Ewing, NJ $08628<$ morrisja@tcnj.edu> \\ ${ }^{2}$ Department of Biology, Loyola University Maryland, Baltimore, MD 21210 \\ ${ }^{3}$ Department of Biology, Loyola University Maryland, Baltimore MD 21210
}

January 11, 2022

\begin{abstract}
Plants in suburban forests of eastern North America face the dual stressors of high white-tailed deer density and invasion by nonindigenous plants. The combination of chronic deer herbivory and strong competition from invasive plants could alter a plant's stress- and defense-related secondary chemistry, especially for long-lived juvenile trees in the understory, but this has not been studied. We measured foliar total antioxidants, phenolics, and flavonoids in juveniles of two native trees, Fraxinus pennsylvanica (green ash) and Fagus grandifolia (American beech), growing in six forests in the suburban landscape of central New Jersey, USA. The trees grew in experimental plots that had been subject for 2.5 years to factorial treatments of deer access/exclosure X addition/no addition of the nonindigenous invasive grass Microstegium vimineum (Japanese stiltgrass). As other hypothesized drivers of plant secondary chemistry, we also measured non-stiltgrass herb layer cover, light levels, and water availability. Univariate mixed model analysis of the deer and stiltgrass effects and multivariate structural equation modeling (SEM) of all variables showed that both greater stiltgrass cover and greater deer pressure induced antioxidants, phenolics, and flavonoids, with some variation between species. Deer were generally the stronger factor, and stiltgrass effects were most apparent at high stiltgrass density. SEM also revealed that soil dryness directly increased the chemicals; deer had additional positive, but indirect, effects via influence on the soil; in beech PAR positively affected flavonoids; and herb layer cover had no effect. Juvenile trees' chemical defense/stress responses to deer and invasive plants can be protective, but also could have a physiological cost, with negative consequences for recruitment to the canopy. Ecological implications for species and their communities will depend on costs and benefits of stress/defense chemistry in the specific environmental context, particularly with respect to invasive plant competitiveness, extent of invasion, local deer density, and deer browse preferences.
\end{abstract}




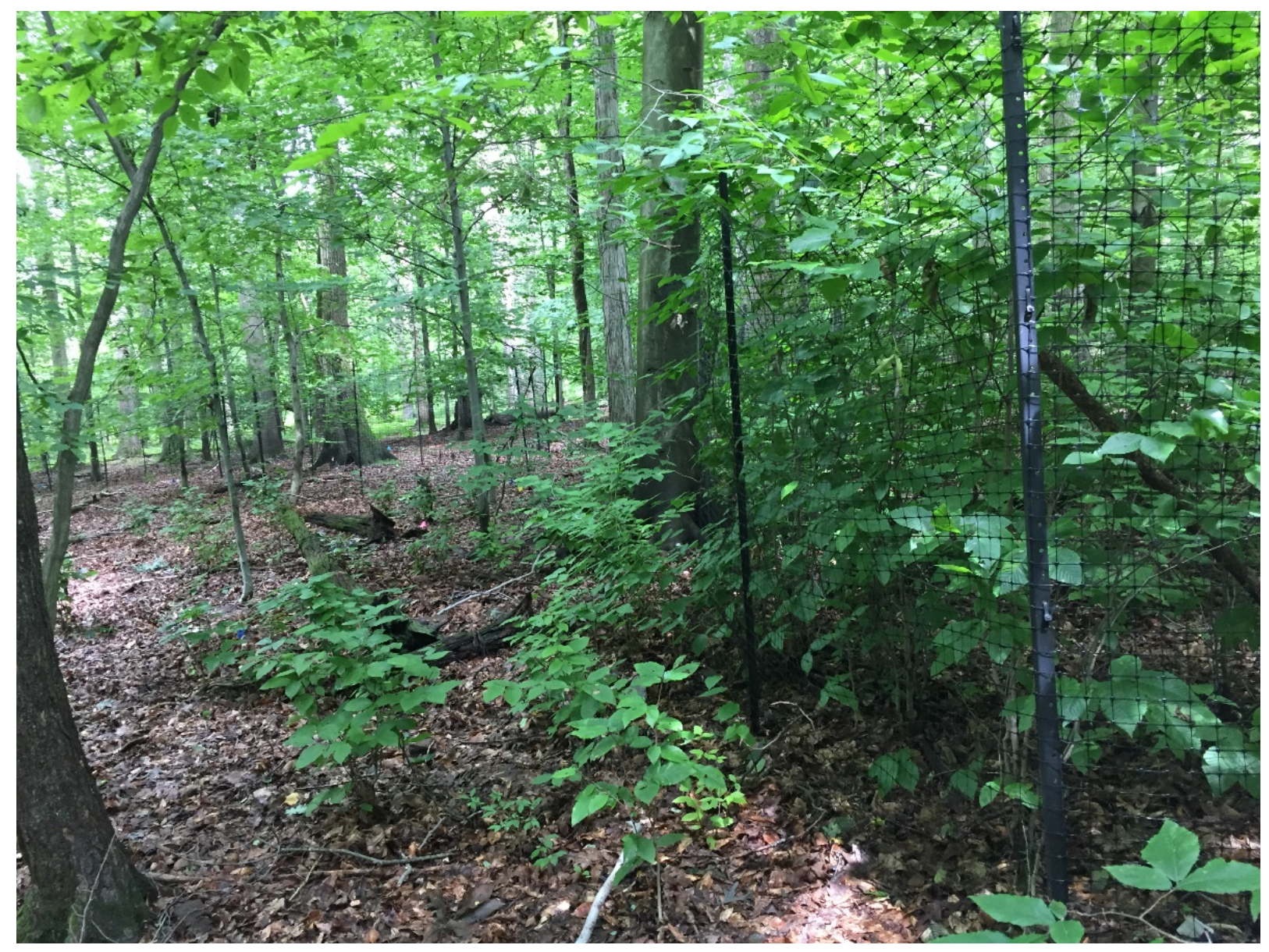

Figure 1: Recovery of suburban forest vegetation in a deer exclosure

\section{1 | INTRODUCTION}

Woodland plants within a suburban landscape live in circumstances that differ in many ways from rural environments with fewer anthropogenic influences, including the presence of many nonindigenous, invasive plant species and very high white-tailed deer (Odocoileus virginianus Zimmerman) densities . Fragmentation of suburban natural areas creates a high edge to interior ratio, creating many entry points for nonindigenous species and rapid spread via trails and roads. In suburban forests, the combination of forest patches with open areas is excellent deer habitat, while hunting is very limited and most natural predators of deer are uncommon. These features of suburban forests cause plants to face the dual stressors of competition from spreading nonindigenous species and deer herbivory, but no studies have investigated plants' chemical responses to these combined stressors. Here, we report on the foliar antioxidant, phenolic, and flavonoid responses in juveniles of two native tree species in forests of suburban New Jersey, USA.

The ability of plants to respond to biotic and abiotic stressors depends on regulatory networks that help balance resource allocation to growth or defense . Reactive oxygen species (ROS) increase during stress, causing oxidative destruction of cells, but this can be countered by antioxidants, which play a scavenging role and minimize plant cell damage . Overall antioxidant production, or more specific categories of antioxidants such as phenolics or flavonoids (a type of phenolic), can act as proxies for the degree of stress experienced by plants. Phenolics and flavonoids have dual roles as antioxidants and inducible defenses; they defend plant 
tissues against future herbivory, scavenge ROS involved in signaling bursts as a result of wounding, and play a role in a generalized stress response. Thus, we may expect antioxidants in general, and phenolics and flavonoids in particular, to increase in suburban woody plants subjected to the dual stressors of invasive plants and chronic deer pressure.

Nonindigenous, invasive plants can broadly influence plant communities through direct effects, e.g. strong competition for resources and allelopathy from plant chemicals, and indirectly via modifications of biotic factors such as microbial communities and natural enemies, or of abiotic factors such as light and moisture availability. How such impacts from invasive plants in particular may influence secondary chemistry of resident plants has not been studied. However, plant competition in general causes various stress responses, with increased antioxidants, phenolics, and flavonoids, or alteration of the overall metabolomic profile . Exposure to competitors' allelopathic chemicals also can alter a plant's secondary chemistry . Therefore, competition from nonindigenous, invasive plants, especially those with allelopathic effects, could elicit strong chemical responses in the native community. Negative trade-offs between defense and competitive ability also are possible, so a resident plant faced with a new plant invader may be particularly vulnerable due to both strong competition and the cost of chemical response to that competition.

Browsing by ungulates also can broadly influence plant communities. White-tailed deer are selective generalists, but exhibit an array of preferences for woody species, which can influence recruitment, shift canopy composition, and extirpate rare species . Browsing on woody plants can lead to induction of defense chemicals; phenolics and flavonoids have been shown to increase after damage. Defense chemicals can reduce palatability to deer, but they also can be correlated with slower growth rates due to trade-offs between growth and defense, which can leave plants vulnerable as they remain within the reach of deer .

Recent work compares the ecological effects of nonindigenous plant invasion and deer pressure on native communities, but has not compared the chemical responses of native plants to both stressors. Given the protective role of plant secondary chemistry, but also its possible physiological cost, such a comparison will aid our understanding of the relative importance of invasive plants and abundant deer in suburban plant communities. We hypothesized that both would prompt increased production of antioxidants, phenolics, and flavonoids in woody plants in our experiment, with the greatest responses under both stressors together, but we posed no a priori hypothesis about their relative importance.

The analysis of ecological experiments benefits from combining univariate methods with multivariate structural equation modeling (SEM) pp. 233-258) that focuses on system-wide responses . We therefore also proposed a system-wide hypothesis (Fig 1), represented as a structural equation meta-model (SEMM). This hypothesis predicted that plant chemical responses would be increased by deer pressure and a new invader, as presented above, but additionally would increase due to direct effects from competition with the rest of the herb layer and from abiotic stressors known to influence secondary chemistry, specifically light and soil moisture. We also hypothesized that deer pressure and abiotic stressors would indirectly decrease the chemical responses via negative direct effects on the herb layer. For example, if herb layer plants declined due to an abiotic stress like drought, then there would be less stress from competition and a decreased chemical stress response in the target plants experiencing that competition. We limited the new invader's hypothesized effect to just that on plant chemistry because we had not observed any strong relationships between the manipulated invasive species in the experiment, Microstegium vimineum (Trin.) A. Camus (Japanese stiltgrass), and the other variables in the model.

\section{2 | MATERIALS AND METHODS}

\subsection{Study sites and species}

Experimental plots $\left(16 \mathrm{~m}^{2}\right)$ were located in six forest stands within a suburban region of central New Jersey, USA, in Hopewell and Princeton Townships, Mercer County. The 131-174 year old stands consist of closed canopies of mixed deciduous trees. The dominant canopy species in the forests are maples (Acer rubrum, A. saccharum ), oaks (Quercus rubrum, Q. velutina, Q. alba, Q. prinus ), hickories (Carya spp.), tulip poplar (Liriodendron tulipifera), American beech (Fagus grandifolia), green ash (Fraxinus pennsylvanica), 
sour gum (Nyssa sylvatica), and sweet gum (Liquidambar styraciflua). Their soils are silt loam or loam with $0-12 \%$ slopes (Natural Resources Conservation Service Web Soil Survey). Deer density in the area was estimated at 32 deer $/ \mathrm{km}^{2}$, exceeding or similar to densities in studies that have shown significant influences on the vegetation of other eastern deciduous forests similar in species composition to the forests we studied . They represent a sample of the fragmented forest parcels in the region, and display a range of ambient deer pressure (Table 1).

The two native, woody species that were the subject of this foliar chemistry study were Fagus grandifolia Ehrh. (American beech) andFraxinus pennsylvanica Marsh. (green ash). Both were common enough in the herb layers of the forests for our investigation, with the exceptions that Curlis Lake Woods had insufficient ash and Nayfield Preserve had insufficient beech to be included. A 2015 deer browse survey in the forests (unpublished data) showed that both species were browsed by deer, with $16.8 \%$ of beeches (total $\mathrm{N}=143$ ) and $1.4 \%$ of ashes (total $\mathrm{N}=559$ ) exhibiting the tell-tale shredded twig tips indicative of deer browse. Study of both beech and ash allowed for consideration of the relative impact of deer preference on foliar chemistry.

It is worth noting that deer preferences and browse rates can vary widely among regions. Therefore, the browse rates measured in our central New Jersey forests should be seen as specific to our study and not applicable to other forests, which likely have lower or higher browse rates on beech and ash. For example, one review of beech ecology reflected the view that deer rarely feed on beech. Other studies have shown $40 \%$ deer browse rates on beech and ash , $18 \%$ on beech, a range from $0 \%$ to $11 \%$ on beech depending on the site characteristics, and widely variable per-plant browse intensity for both species .

\section{$2.2 \mid$ Experimental design}

In each forest, 32-40 $16 \mathrm{~m}^{2}$ plots were arranged on a grid with $4 \mathrm{~m}$ between plots. Each plot was randomly assigned a fencing or no-fencing treatment and a stiltgrass seed addition or no-addition treatment. The fences were installed in spring 2013. They were $2.3 \mathrm{~m}$ tall, consisting of plastic material with $4 \times 4.5 \mathrm{~cm}$ mesh, made for deer exclosures (Deerbusters.com). The fencing was staked to the ground but had three cut-outs at ground level on each side. This allowed entry by rabbits and voles and ensured that the only excluded herbivore would be deer. This fencing has no effect on light or wind speed. Any leaf litter that accumulated against the fences in the border was removed twice per year, and vines that began to grow up the fences were clipped away as needed.

The stiltgrass seed addition treatment was applied in fall 2012. Each addition plot received $2.95 \mathrm{~g}$ of locally collected, pooled seeds (approximately 2,420), mixed with $75 \mathrm{ml}$ sand for easier distribution, after which the leaf litter and the soil surface were disturbed with a stout stick, allowing the seeds to settle down onto the soil surface (the no-addition plots were disturbed in the same manner). We used this randomly assigned stiltgrass addition treatment to avoid any confounding site effects that could be associated with naturally occurring stiltgrass abundances. The seed additions were done after gaining permission from the forest preserve owners. Stiltgrass was not present in the specific study sites prior to the experiment, but was common elsewhere in the forests, as in nearly all forested areas of central New Jersey (personal observations). It is important to note that stiltgrass was removed where it appeared in the study sites outside of addition plots, and when ongoing research in the sites is concluded, it will be removed from addition plots until the seed bank is depleted. Subsequent recruitment and persistence of the introduced stiltgrass was highly variable among forests and plots, providing a range of densities that aligned with those found in naturally occurring stands in these forests: from nearly zero to nearly $100 \%$ cover

We manipulated stiltgrass, specifically, because it is one of the most common and abundant invasive herb layer species in the region, and it has many documented negative effects on invaded plant communities . However, no research exists on its possible effects on indigenous plants' foliar chemistry. There were other, naturally-occurring, nonindigneous, invasive plant species present in all of the forests and many of the plots, but they varied among the forests and most were shrubs with low percent cover. The only herbaceous invasive plant with substantial cover was Japanese honeysuckle (Lonicera japonica), but the most cover it had in any plot was only $9 \%$, and its average cover was $0.8 \%$ and median cover was zero. 


\section{$2.3 \mid$ Leaf collection}

All leaves from beech and ash used in the study were collected on 2 Sept 2015. The number of plots sampled from each forest varied, based on the presence of beech and ash. In order to avoid biasing the results by tree age/size, in each sampled plot leaves were collected from one juvenile plant in each of three distinct size classes, as possible based on availability. If multiple plants in a size class were present, they were numbered and a random number generator dictated the choice. For ash, the size classes were: $0-10 \mathrm{~cm}, 20-40 \mathrm{~cm}$, $50-140 \mathrm{~cm}$. For beech they were: only one set of simple leaves present, compound leaves with stem height $<$ $20 \mathrm{~cm}$, compound leaves with stem height $>25 \mathrm{~cm}$. The two most distal (youngest) leaves were removed from all ashes and from unbranched beeches; for branched beeches, the most distal leaf on the lowest branch and the terminal branch were used. Leaves were collected from beech in five forests (not Nayfield), from 18 to 35 plots per forest and 19 to 53 plants per forest, with 101 plants from fenced plots and 83 from unfenced plots. Ash leaves were also taken from five forests (not Curlis), including 18 to 39 plots per forest and 30 to 95 plants per forest, with 163 in fenced plots and 156 unfenced. The two leaves from one plant were put into one envelope and then dried at $50^{\circ} \mathrm{C}$ for three days, in preparation for chemical analysis.

\section{$2.4 \mid$ Foliar chemical analysis}

We measured three categories of non-enzymatic antioxidants, from most to least inclusive: total antioxidants, total phenolics, and total flavonoids. Leaf samples $(30 \mathrm{mg}+/-0.1 \mathrm{mg}$ dry weight) were taken from multiple parts of the leaf for both leaves within a sampled plant. The leaf samples were mixed with clean sea sand in a $1.5 \mathrm{ml}$ microcentrifuge tube and ground into a fine powder before extraction with $1.52 \mathrm{ml}$ of methanol. The tube was vortexed for 10 seconds; then the samples were put in a shaker at $150 \mathrm{rpm}$ at $25{ }^{\circ} \mathrm{C}$ for 60 minutes. The samples were then centrifuged for 5 minutes at 5,000 RPM, followed by removal of the supernatant. Assays for antioxidant capacity, phenolic concentration, and flavonoid concentration were conducted on the supernatant.

Antioxidant capacity was analyzed in a 48 well plate using the FRAP assay according to . In brief, $900 \mu \mathrm{L}$ of FRAP reagent was added to $30 \mu \mathrm{L}$ of sample and $90 \mu \mathrm{L}$ of ultrapure water, incubated for 4 minutes, and absorbance read at $593 \mathrm{~nm}$ on UV-Vis spectrometer. The standard curve was generated using Trolox from 0-1500 $\mu$ mole per liter. Antioxidant capacity of the samples is expressed as Trolox Equivalents (TE) per gram dry weight.

Phenolic concentration was tested using the Folin-Ciocalteu method. In brief, $20 \mu \mathrm{L}$ of the sample was mixed with $60 \mu \mathrm{L}$ of Na2CO3, $900 \mu \mathrm{L}$ of ultrapure water and $20 \mu \mathrm{L}$ of three-fold diluted Folin-Ciocaltue reagent. The samples were then vortexed and left to sit at room temperature for 2 hours. Absorbance was read at $760 \mathrm{~nm}$. Gallic acid (0 to $0.4 \mathrm{mg}$ per $\mathrm{ml}$ ) was used to generate the standard curve. Phenolic concentration of the samples is expressed as Gallic Acid Equivalents (GAE) per gram dry weight.

Flavonoid concentration was analyzed in a 48 well plate using the aluminum chloride precipitation . 100 $\mu \mathrm{L}$ of sample was added to $400 \mu \mathrm{L}$ of ultrapure water. $30 \mu \mathrm{L}$ of NaNO2 was added and allowed to sit for 5 minutes, followed by addition of $30 \mu \mathrm{L}$ of AlCl3. After 1 minute, $400 \mu \mathrm{L}$ of $\mathrm{NaOH}$ was added. The absorbance was immediately measured at $510 \mathrm{~nm}$. (+)-Catechin (0-1,000 ppm) was used to generate the standard curve. Flavonoid concentration of the samples is expressed as Catechin Equivalents (CE) per gram dry weight.

\section{5 | Field data collection}

The proportion cover of all herb layer plants was quantified in each plot before leaf drop in the fall of 2015 . Each species' cover was scored as $<1 \%, 1-10 \%, 11-20 \%, 21-30 \%$, etc. (in $10 \%$ intervals up to $100 \%$ ) in 0.25 $\mathrm{m}^{2}$ quadrat frames, which were dropped without looking into each $1 \mathrm{~m}^{2}$ section of the $16 \mathrm{~m}^{2}$ plot. The score was converted to the interval's midpoint, and the mean of the 16 values provided one cover value per plot for each species, including stiltgrass. The values for all other species were summed to calculate the cover for all non-stiltgrass plants in the plot.

Photosynthetically active radiation at ground level was measured in each plot with a 1 meter long ceptometer (AccuPAR model PAR-80 by Decagon Devices, Pullman, Washington, USA). Measurements for a plot were 
made under cloudless conditions between 10 am and $2 \mathrm{pm}$ of one day, at the four corners and center of each plot, and in nearby fields for full-sun measures. Percent of full-sun PAR was calculated for each plot by dividing the average of the five in-plot readings by the full-sun values from the same time point, and multiplying by 100 . The measurements were done from 16 July to 20 October, as weather and schedules allowed, before leaf drop except for canopy ash trees (they were uncommon near the plots measured in October).

Soil water potential was measured as $\mathrm{mPa}$ with a bench-top WP4 soil water potential meter (also Decagon Devices) on two soil samples taken from the top $3 \mathrm{~cm}$ of each plot on 14 September 2014. To capture conditions when variation in soil moisture could be detected, we ensured each collection was made when there had been a light rain the previous day $(6 \mathrm{~mm})$ and no rain for the six previous days.

We calculated an ambient deer browse index (DBI) for each forest to use in the SEMs. It consisted of the proportion of deer-browsed individuals in unfenced plots of five native plant taxa: Carya spp.,F. grandifolia, Fraxinus pennsylvanica, Acer rubrum, and Rubus allegheniensis. These were included because they were sufficiently common in the forests' understories to allow for one index applicable to all of the forests and because they were, in our sites, neither the most browsed species nor completely avoided by deer. Other studies have used one sentinel species for a browse index. However, in our suburban forests with varying deer pressure and some very depauperate herb layers, no one species was suitable as a consistent indicator among forests. An index with multiple species offers a robust measure when species' frequencies are highly variable among sites, as in our forests. Deer browse is readily identifiable. Deer have no upper incisors so they bite up on the stem, causing distinctive shredded tips, whereas a rodent clips the stem and leaves a clean, angled tip . Deer browse data were collected in 16 to 20 unfenced plots per forests; within each plot all woody and semi-woody individuals in a $0.5 \times 7.5$ belt transect were examined for the presence of deer browse.

\section{6 | Statistical analysis - Mixed models}

We analyzed separate mixed models for antioxidant capacity, phenolic concentration, and flavonoid concentration, using PROC MIXED in SAS v 9.4. Where enough plants were available, we collected leaves from three plants per species per plot for chemical analysis (in the plots where the species was present), but there were plots with just one or two plants of ash or beech. Therefore, the analyzed response variable was the mean value for all sampled individuals in a plot, thereby providing one value per plot. To normalize model residuals, all response variables were $\log _{10}$ transformed, except for ash flavonoids, which were square-root transformed. All models were randomized complete blocks, with "forest" the random blocking factor (five forests). Fixed effects were "fencing" (either 'fence' or 'no fence') andMicrostegium vimineum (stiltgrass) percent cover ("mivi"), with four categorical levels based on the ranges of cover resulting from the experimental seed treatment: $0 \%, 0.03 \%-1.3 \%, 1.6 \%-5.6 \%, 12.2 \%-65 \%$. Using these categories allowed us to test the idea that stiltgrass cover may have a threshold effect on foliar chemistry. The models also included the "fencing x mivi" interaction term. The omnibus tests were considered significant when $\mathrm{P}<0.05$. Because we hypothesized that greater competition for the invasive species would increase the foliar chemicals, we did planned comparisons among all stiltgrass cover levels, using the Tukey-Kramer method to adjust for mutliple contrasts and unequal sample sizes. If the omnibus test was only close to significant $(\mathrm{P}<0.10)$, we still reported it to avoid ignoring a potentially causal relationship and conducted the planned multiple comparisons, following .

\subsection{Statistical analysis - Structural equation modeling}

We conducted structural equation modeling with the 'piecewiseSEM' package v. 2.0 in $\mathrm{R}$ v. 4.0 .3 using $\mathrm{R}$ Studio v. 1.2.5001. In this method, the psem() function was applied to the set of multiple linear regressions, built with $\operatorname{lm}()$, that were specified in initial structural equation measurement models (Fig. 2A and 2B) based on the proposed concepts and pathways in the conceptual SEMM (Fig. 1) and informed by the results of the univariate mixed models. Specifically, the initial measurement models did not include paths from the deer browse pressure variable or stiltgrass cover to a chemical group if the fencing effect or stiltgrass cover 
effect was not signficant in the mixed model. Using such prior knowledge of a system when developing an iniital model is a key practice in structural equation modeling. Antioxidants, phenolics, and flavonoids as described above measured the 'plant chemical response' concept from the SEMM; the ambient DBI measured 'deer browse pressure' in unfenced plots and was set to zero for fenced plots; a stiltgrass cover category, with four levels, measured 'competition from new invasion'; the total non-stiltgrass proportion cover measured 'other herb layer competition'; and soil dryness (-1 x soil water potential) and percent of full-sun PAR measured 'abiotic stressors'.

Note that stiltgrass cover and DBI were exogenous variables in the SEM, with no paths to them from other variables. This was because they were experimentally manipulated; by design, half of the plots had zero stiltgrass and the half that were fenced had zero deer browse pressure. Additionally, none of the mixed models indicated an interactive effect of deer exclosure fencing and stiltgrass cover on any of the foliar chemical groups, which supported not having any indirect paths from stiltgrass cover to the chemicals through the deer browse index, or vice versa.

All endogenous variables in the model were first transformed to better normalize the residuals from their regressions, which were checked by the Shapiro-Wilk statistic and with visualizations produced by the 'fitdistrplus' package v. 1.1-1. Good transformations were indicated by the 'bestNormalize' package v. 1.6.1 , and included either $\log _{10}$ or square root transformations. In addition, prior to modeling, we removed several outliers and checked for any nonlinearities between variables by plotting the data and fitting various nonlinear functions in Excel. In no case was it necessary to include nonlinear relationships in the SEM regressions. The Fisher's $\mathrm{C}$ statistic indicated model fit . The modeling process was iterative. We began with the hypothesized measurment models in Figures $2 \mathrm{~A}$ and $2 \mathrm{~B}$, then removed nonsignificant paths and added any significant and ecologically sensible paths that were indicated by psem() to be necessary for model fit.

\section{3 | RESULTS}

\section{1 | Mixed models}

Ash - Foliar antioxidant concentration of ash plants was significantly greater in unfenced plots compared to fenced plots $(\mathrm{P}=0.02$, Figure $3 \mathrm{~A})$. Stiltgrass cover level had a marginal overall effect on ash antioxidant capacity $(\mathrm{P}=0.10)$, with somewhat greater mean values in plots with $12-65 \%$ stiltgrass cover versus zero cover $(\mathrm{P}=0.09$, Figure $3 \mathrm{~B})$. There was no significant interaction between fencing and stiltgrass cover for ash antioxidants. Only the fencing treatment had a significant effect on phenolics $(\mathrm{P}=0.01)$ and flavonoids $(\mathrm{P}=0.05)$ in ash, with greater mean values for plants in the unfenced plots (Figures 3C, 3D).

Beech - Stiltgrass cover level significantly affected antioxidants in beech $(\mathrm{P}=0.05)$, with significantly greater mean concentrations in plots with the $12-65 \%$ cover level compared to the $>0-1.5 \%$ cover level (Figure $4 \mathrm{~A}$ ). Flavonoids showed the same overall trend $(\mathrm{P}=0.08$; Figure $4 \mathrm{~B})$. Neither beech antioxidants nor flavonoids were affected by the fencing treatment or its interaction with stiltgrass cover. Beech phenolics were not affected by deer, stiltgrass cover, or their interactions.

One goal of the initial experimental design was to test the hypothesis that the dual stressors of competition from high stiltgrass cover and chronic deer browsing would cause the greatest increases in foliar secondary chemicals. This could have been indicated from significant fencing $\mathrm{x}$ stiltgrass cover level interactions, but none were detected in the full models. We had expected the stiltgrass seed addition treatments to result in uniformly high cover of stiltgrass, but this occurred only in a small number of plots scattered across the forests. Therefore, as another test of this hypothesis, for each species-chemical combination we did a set of simple planned comparisons between four groups (pooled across the forests): fenced/zero stiltgrass cover, fenced/high stiltgrass cover, unfenced/zero stiltgrass cover, unfenced/high stiltgrass cover. High cover was defined as $>12 \%-65 \%$. For four of the six species-chemical combinations there were no significant contrasts between any groups. However, ash antioxidant values were greater in the unfenced/high cover group vs. the fenced/zero cover group and the unfenced/zero cover group (Figure 5A), and beech phenolics were greater in the unfenced/high cover group vs. the fenced/zero cover group (Figure 5B). 


\subsection{Structural equation models}

Ash - We arrived at a final, fitted SE model (Fig. 6A) that both reinforced many of the findings above for ash, and also provided additional insights. First, as in the univariate mixed models, the SEM revealed a strong, direct, positive effect of stiltgrass cover on antioxidants and no effect on phenolics or flavonoids. Second, as in the univariate models, deer browse pressure (measured as DBI) positively affected antioxidants and phenolics, but did not affect flavonoids, mirroring the somewhat weaker effect of fencing on flavonoids ( $\mathrm{P}=0.05$ vs 0.01 and 0.02 for the other chemicals). DBI had a strong negative effect on herb layer cover, but there was no signficant effect of the herb layer on any foliar chemicals. Third, the two abiotic variables in the ash SEM were very influential, with various strong direct and indirect effects on foliar chemistry, e.g. greater concentrations of all three chemical types with increasing soil dryness and a direct positive effect on flavonoids from increased PAR.

Beech - The final SEM for beech also provided many similar findings as the univariate models, along with some new and different results (Fig. 6B). First, as in the univariate models, stiltgrass cover positively influenced antioxidants and flavonoids, but not phenolics. Second, DBI had direct, positive influences on all three chemical types, in addition to a net positive effect via the indirect pathway through soil dryness, which differed from the univariate analysis in which there were no significant effects of deer exclosure fencing. As in the ash SEM, deer had a very strong negative effect on the other herb layer vegetation, but that in turn had no paths to the beech chemical variables. Third, all chemical concentrations increased with greater soil dryness, but PAR did not have any effects and was dropped from the model.

Overall, the SEMs suggested that 1) deer and abiotic factors had greater influences on leaf chemistry than did the invasive species $M$. vimineum or competition from other plants; 2) although the three chemicals' values were positively correlated, as expected, they did not respond identically to the variables and were more similar in the beech SEM; 3) a substantial amount of variation in the models remains to be explained by unmeasured factors.

\section{4 | DISCUSSION}

\section{1 $\mid$ Effects of stiltgrass cover}

This study provided partial support for the hypothesis that a newly introduced, invasive, nonindigenous species can increase foliar antioxidants, phenolics, and flavonoids of plants in the invaded community. Support was shown in both types of analysis, by the positive SEM paths from stiltgrass cover to ash and beech antioxoidants and beech flavoinoids and by the significant effect of stiltgrass cover level on beech antioxidants in the univariate model. In addition, there were several contrasts $(\mathrm{P}<0.09)$ in the univariate models between the highest stiltgrass cover level and the zero or $>0-1.5 \%$, suggesting that high stiltgrass cover may have caused greater antioxidants in ash and flavonoids in beech. However, stiltgrass had no effects on phenolics in either species or flavonoids in ash, except indirectly in the SEM via correlations between the chemical groups. Ash and beech are mid- to late-successional tree species, respectively. They may remain as juveniles for years, and so must contend with long-term competition from plants in the herb layer, which can be intense from a rapidly increasing invader, potentially limiting resources, depressing growth rates, and reducing a tree's chance of reaching the canopy. If the competition also induces increased production of secondary chemicals, as observed here in some cases, the plants may incur an added cost in even lower growth rates, given the possibility of growth-defense tradeoffs. Indeed, such tradeoffs have been documented for induced defenses in woody species .

To our knowledge, no other studies have demonstrated induction of secondary chemistry by a nonindigenous, invasive species, including the well-studied Japanese stiltgrass. Previous research indicates that it has allelopathic potential, and since secondary chemical responses to allelopathy have been shown in other systems, this is a possible mechanism worth further study. Stiltgrass's influence likely relies on it reaching a certain threshold of density during invasion; in our study its influence was generally due to its highest cover level.

The differences among the species-chemical combinations for the effects of stiltgrass have several possible 
explanations. Plant secondary chemistry is influenced by a wide array of factors (e.g. resource availability, ontogeny), and variation in their production is common within populations and communities. The data sets for each species came from a somewhat different set of forests and plots, so they may have experienced different resource conditions that mediated the competitive impact of stiltgrass. Competition intensity can alter chemical responses as shown, for example, in a study where specific flavonoids increased under low competition but decreased under high competition. The stronger influence of stiltgrass on flavonoids in beech vs. ash could be due to beech's greater shade tolerance. Its slower growth rate in the herb layer may allow it to invest more in secondary chemicals than the faster-growing ash, as has been predicted by the Resource Availability Hypothesis and shown, particularly for forest tree seedlings . Total antioxidants in ash were directly affected by stiltgrass, but phenolics and flavonoids were not; it is likely the case that antioxidants other than phenolics were induced by stiltgrass competition. These differences could be resolved with a metabolomics approach in future research.

\section{$4.2 \mid$ Effects of deer pressure}

The hypothesis that deer pressure increases foliar concentrations of antioxidants, phenolics, and flavonoids was also partially supported for both species in this study. For ash, all three chemical groups were significantly greater in unfenced plots versus fenced plots, as shown by the univariate analyses. The SEM also indicated a positive effect of the deer browse index on ash antioxidants and phenolics, but not on flavonoids, except indirectly through the other chemical groups. For beech, a positive effect of deer on all three foliar chemical groups was apparent in the SEM, but the mixed models showed no signficant effects from the fencing treatment. These induced chemical responses to deer pressure could have been recent or even months old, as long-lasting effects on induced defenses have been shown previously for woody species, including in Fagus and Fraxinus. The responses to deer can have two functions with ecological implications for browsed plants. On the one hand, they can become more protected against future browse, which should be very beneficial for growth and survival and could create an advantage in the plant community of suburban forests with high deer densities. On the other hand, if there is a substantial cost to induced defenses, a browsed woody plant could experience double jeopardy: loss of tissue coupled with lower growth potential that prevents it from escaping above the browse line. However, we cannot always assume a cost of induced defense. Which scenario applies will depend on the relative costs and benefits, which rely on a complex suite of intersecting factors, e.g. the level of herbivory pressure, competition, and tolerance traits.

Beech was browsed much more frequently than ash in the forests of this study, so we would expect it to have stronger secondary chemical responses to deer. This was indicated by the SEMs, but the mixed models suggested that ash was more affected. We have no specific explanation for this difference, except to note that SEM is a multivariate approach that is more representative of real ecological communities. Even so, given the low browse rate on ash in these forests, it seems to have mounted a strikingly strong chemical response to deer pressure.

\subsection{Effects of plant invasion + deer pressure}

The hypothesis that deer pressure and the invasive species together would cause the greatest foliar chemical responses was partially supported in this study. Although the availability of data for plots with high stiltgrass was limited, we still detected significantly greater ash antioxidants and beech phenolics in the plots with the dual stressors of deer access (unfenced) and high stiltgrass cover compared to the plots with neither stressor (fenced, zero stiltgrass), whereas high stiltgrass cover or unfenced treatment alone did not cause a significant increase in beech phenolics. However, there were no differences among the treatment groups for any of the other species-chemical combinations, and no significant fencing $\mathrm{x}$ stiltgrass cover level interaction terms in the full mixed models. Still, these results illustrate that some woody plants experience an enhanced secondary chemical response when faced with multiple stressors. The roles of multiple stressors in biological systems is increasingly recognized across disciplines, and has specifically been documented for deer pressure combined with earthworm invasions, non-native plant invasion, and herbivory by rodents .

\subsection{Relative strengths of plant invasion and deer pressure effects}


We sought to determine which factor - plant invasion or deer pressure - had greater influence on plant secondary chemistry. The SEMs suggest that, in this study, deer pressure was the more important factor. It had direct positive influences on nearly all of the chemical groups. Additionally, greater deer pressure in the SEM increased soil dryness in the beech SEM, which in turn increased antioxidants, phenolics, and flavonoids. In contrast, no strong indirect paths from stiltgrass to the chemicals were apparent, and while the strengths of the signficiant direct paths from stiltgrass cover to the chemical variables $(0.18,0.28,0.21)$ were similar to those from the deer browse index variable $(0.26,0.24,0.21,0.21,0.24)$, there were fewer of these direct paths. The univariate analyses were mixed on this point, showing stronger effects of deer on ash foliar chemicals, but stronger effects of stiltgrass cover in beech.

A recent review of published deer-invasive plants experiments concluded that deer are generally a more influential factor in deciduous forest communities of eastern North America than are invasive plants. Our research provides a new dimension to this comparison: for at least some woody species, deer pressure likely placed greater demands on plant secondary chemistry than competition from an invading plant. Even so, it is perhaps more important to recognize that both stressors induced responses in both species, and with a more widespread invasion, stress from stiltgrass competition likely would increase. In our study, effects from free-ranging deer were likely much more spatially homogenous and widespread than that of the patchy $M$. vimineum, which invaded some plots much more readily than others.

\section{5 | Dual analysis: univariate models and structural equation modeling}

One reviewer objected to presenting two different statistical philosophies, one rooted in experimental design (univariate mixed models) and the other in observational data analysis (SEM). While this reviewer felt that we should choose one or the other to present, like other authors we think that the two different approaches complement each other and provide a more holistic picture of what is driving the induction of foliar chemistry in young saplings of two woody species. The experiment was designed to test for main effects of and interactions between deer exclosure fencing and stiltgrass cover, as in any standard factorial design. The univariate analyses revealed these effects, but they also helped guide development of the intitial SE measurement model. In turn, the fitted SEMs provided additional insight into the univariate results. Specifically, they confirmed the positive influences of stiltgrass cover only on antioxidants for ash and, for beech, on just antioxidants and flavonoids. However, it turned out that significant paths did exist between the deer browse index and all of the beech chemical groups. The fencing effect in the mixed models only compared fenced and unfenced plots, without taking into account any important variation in ambient deer pressure among the forests, which could affect the unfenced plots. The SEMs' deer browse index, however, was modeled in a regression context, with deer browse pressure estimates for the unfenced plots that were distinct for each forest, and this variation in ambient deer browse pressure was important for most of the foliar chemicals. The larger context of the SEM also allowed for consideration of the relative importance of the experimental treatments when modeled alongside other drivers in the system. For example, stiltgrass cover significantly increased antioxidants in beech in the mixed model, but in the SEM its positive path was weaker than the effect of droughty soil.

\subsection{Other variables as drivers in the SEM: herb layer cover, soil dryness, and PAR}

Not surprisingly, in both ash and beech SE models, there was a strong negative effect of deer on the nonstiltgrass herb layer cover. We had hypothesized in the structural equation meta-model that, in turn, this reduced cover would cause less competitive stress on beech and ash juveniles, thereby decreasing their antioxodants, phenolics, and flavonoids. This would therefore have revealed a positive, indirect effect of deer on the foliar chemistry. However, the SEM did not show any effects on beech and ash foliar chemistry due to the non-stiltgrass cover. This contrasts to the positive effect that stiltgrass cover had, suggesting that greater stress was caused by the invasive species.

Soil dryness had direct, positive effects on each of the three chemicals in the SEMs, for both species. Levels of antioxidants are generally increased under drought stress. For example, studies of Quercus ilex, which shares beech's family (Fagaceae), found increased phenolic production under drought conditions, and flavonoids 
have been proposed as a secondary antioxidant system activated in severe stress . Beech and ash exhibited somewhat different strengths of their chemical responses to drought stress, which is not surprising. Within Quercus, for example, three species had different foliar concentrations of antioxidants in response to drought , and even within a species local adaptation can result in different strategies for drought stress tolerance .

Photosynthetically active radiation (PAR) signficantly, positively affected flavonoids in ash, but not in beech. High PAR can lead to excess excitation energy, resulting in reactive oxygen species (ROS) production that may cause damage to photosystems I and II. ROS produce signaling cascades that adjust metabolism using a variety of stress-protective mechanisms, including non-enzymatic antioxidants . For example, excess light is known to upregulate the production of flavonoids, which act as ROS scavengers and are involved in photoprotection. In the ash SEM, PAR also had indirect, positive effects on all three chemical groups through its positive effect on soil dryness, which in turn had positive effects on the chemical levels.

The SEMs were designed to include major factors that we hypothesized to be important drivers of plant secondary chemistry in the forests. They revealed a number of significant paths, but the explained variation ( $\mathrm{R}^{2}$ values) for the three chemical groups ranged only from $0.13-0.33$. Intraspecific variation in specific types of secondary metabolites and the overall metabolome is common, with many possible causes . Our research has uncovered several important drivers in suburban forests, but other factors that were not considered in our models also must be influential and are important for future study (e.g. plant-soil feedbacks, .

\section{5 | CONCLUSIONS}

Suburban forests are important sites for biodiversity, but many have experienced steep declines in step with deer overabundance and nonindigenous plant invasions. Here, we showed that these two common stressors can increase juvenile trees' secondary chemicals involved in defense and stress responses. Deer generally had stronger and/or more consistent effects than stiltgrass and in some cases their combination increased the chemical responses. The SEM analysis revealed additional, important influences on the trees' secondary chemistry. The ecological implications for each species - and the overall suburban forest community - will depend on the relative costs and benefits to each species in their particular environmental contexts, which is a goal for future research in this area.

\section{References}

Adams, S.N. \& Engelhardt, K.A.M. (2009). Diversity declines inMicrostegium vimineum (Japanese stiltgrass) patches.Biological Conservation , 142, 1003-1010.

Afifi, M. \& Swanton, C. (2012). Early physiological mechanisms of weed competition. Weed Science, 60(4), 542-551. https://doi.org/10.1614/WS-D-12-00013.1.

Agati, G., Azzarello, E., Pollastri, S. \& Tattini, M. (2012). Flavonoids as antioxidants in plants: Location and functional significance. Plant Science, 196, 67-76. https://doi.org/10.1016/j.plantsci.2012.07.014.

Alverson, W.S., Waller, D.M. \& Solheim, S.L. (1988). Forests too deer: Edge effects in northern Wisconsin. Conservation Biology, 2(4), 348-358. https://doi.org/10.1111/j.1523-1739.1988.tb00199.x.

Aronson, M.F.J. \& Handel, S.N. (2011). Deer and invasive plant species suppress forest herbaceous communities and canopy tree regeneration.Natural Areas Journal , 31(4), 400-407. https://doi.org/10.3375/043.031.0410.

Aronson, M.F., Handel, S.N., La Puma, I.P. \& Clemants, S.E. (2015). Urbanization promotes non-native woody species and diverse plant assemblages in the New York metropolitan region. Urban Ecosystems, 18(1), 31-45. https://doi.org/10.1007/s11252-014-0382-z.

Ashraf, M.A., Iqbal, M., Rasheed, R., Hussain, I., Riaz, M. \& Arif, M.S. (2018). Chapter 8 - Environmental stress and secondary metabolites in plants: An overview. Plant Metabolites and Regulation Under Environmental Stress (eds P. Ahmad, M.A. Ahanger, V.P. Singh, D.K. Tripathi, P. Alam \& M.N. Alyemeni), pp. 153-167. Academic Press. 
Augustine, D.J. \& McNaughton, S.J. (1998). Ungulate effects on the functional species composition of plant communities: Herbivore selectivity and plant tolerance. Journal of Wildlife Management, 62(4), 1165-1183. https://doi.org/10.2307/3801981.

Augustine, D.J. \& deCalesta, D. (2003). Defining deer overabundance and threats to forest communities: From individual plants to landscape structure. Écoscience , 10(4), 472-486. https://doi.org/10.1080/11956860.2003.11682795.

Ballhorn, D., Godschalx, A., Smart, S., Kautz, S. \& Schädler, M. (2014). Chemical defense lowers plant competitiveness. Oecologia , 176(3), 811-824. https://doi.org/10.1007/s00442-014-3036-1.

Baxter, A., Mittler, R. \& Suzuki, N. (2014). ROS as key players in plant stress signalling. Journal of Experimental Botany , 65(5), 1229-1240. https://doi.org/10.1093/jxb/ert375.

Bee, J.N., Tanentzap, A.J., Lee, W.G., Lavers, R.B., Mark, A.F., Mills, J.A. \& Coomes, D.A. (2011). Influence of foliar traits on forage selection by introduced red deer in new zealand. Basic and Applied Ecology , 12(1), 56-63. https://doi.org/10.1016/j.baae.2010.09.010.

Benzie, I.F.F. \& Strain, J.J. (1996). The ferric reducing ability of plasma (FRAP) as a measure of "antioxidant power": The FRAP assay.Analytical Biochemistry , 239(1), 70-76. https://doi.org/10.1006/abio.1996.0292.

Bilska, K., Wojciechowska, N., Alipour, S. \& Kalemba, E.M. (2019). Ascorbic Acid-The little-known antioxidant in woody plants.Antioxidants , 8(12). https://doi.org/10.3390/antiox8120645.

Blossey, B., Curtis, P., Boulanger, J. \& Dávalos, A. (2019). Red oak seedlings as indicators of deer browse pressure: Gauging the outcome of different white-tailed deer management approaches. Ecology and Evolution , 9(23), 13085-13103. https://doi.org/10.1002/ece3.5729.

Blossey, B., Davalos, A. \& Nuzzo, V. (2017). An indicator approach to capture impacts of white-tailed deer and other ungulates in the presence of multiple associated stressors. AoB PLANTS , 9(5), plx034. https://doi.org/10.1093/aobpla/plx034.

Blossey, B. \& Gorchov, D.L. (2017). Introduction to the special issue: Ungulates and invasive species: Quantifying impacts and understanding interactions. AoB PLANTS , 9(6), plx063. https://doi.org/10.1093/aobpla/plx063.

Brunetti, C., Guidi, L., Sebastiani, F. \& Tattini, M. (2015). Isoprenoids and phenylpropanoids are key components of the antioxidant defense system of plants facing severe excess light stress.Environmental and Experimental Botany , 119, 54-62. https://doi.org/10.1016/j.envexpbot.2015.04.007

Burns, R.M. \& Honkala, B.H. (1990). Silvics of North America. Volume 2. Hardwoods. United States Department of Agriculture (USDA), Forest Service, Agriculture Handbook 654.

Cadenasso, M.L. \& Pickett, S.T. (2001). Effect of edge structure on the flux of species into forest interiors. Conservation Biology , 15(1), 91-97. https://doi.org/10.1111/j.1523-1739.2001.99309.x.

Callaway, R.M. \& Ridenour, W.M. (2004). Novel weapons: Invasive success and the evolution of increased competitive ability. Frontiers in Ecology and the Environment , 2(8), 436-443.

https://doi.org/10.1890/1540-9295(2004)002[0436:NWISAT]2.0.CO;2.

Chalker-Scott, L. \& Fuchigami, L.H. (1989). The role of phenolic compounds in plant stress responses. Low Temperature Stress Physiology in Crops (ed P.H. Li), pp. 67-80. CRC Press.

Champagne, E., Royo, A.A., Tremblay, J. \& Raymond, P. (2020). Phytochemicals involved in plant resistance to leporids and cervids: A systematic review. Journal of Chemical Ecology , 46(1), 84-98. https://doi.org/10.1007/s10886-019-01130-z. 
Cipollini, K. \& Bohrer, M.G. (2016). Comparison of allelopathic effects of five invasive species on two native species. The Journal of the Torrey Botanical Society, 143(4), 427-436. https://doi.org/10.3159/TORREYD-15-00062.1.

Coley, P.D., Bryant, J.P. \& Chapin, F.S. (1985). Resource availability and plant antiherbivore defense. Science, 230(4728), 895-899. https://doi.org/10.1126/science.230.4728.895.

Corbett, B.F. \& Morrison, J.A. (2012). The allelopathic potentials of the non-native invasive plant Microstegium vimineum and the native Ageratina altissima: Two dominant species of the eastern forest herb layer. Northeastern Naturalist , 19(2), 297-312. https://doi.org/10.1656/045.019.0211.

Cote, S.D., Rooney, T.P., Tremblay, J.P., Dussault, C. \& Waller, D.M. (2004). Ecological impacts of deer overabundance. Annual Review of Ecology and Systematics , 35, 113-147. https://doi.org/10.1146/annurev.ecolsys.35.021103.105725

Crimmins, S.M., Edwards, J.W., Ford, W.M., Keyser, P.D. \& Crum, J.M. (2010). Browsing patterns of white-tailed deer following increased timber harvest and a decline in population density. International Journal of Forestry Research , 2010, 1-7. https://doi.org/10.1155/2010/592034.

Darmanti, S., Santosa, Nugroho, L.H. \& Dewi, K. (2018). Reactive oxygen species accumulations, phenylalanine ammonia-lyase activity and phenolic acid composition of soybean [Glycine max (L.) merr.] cv. grobogan that exposed to multiple stress of purple nutsedge (Cyperus rotundus L.) interference and drought. The Journal of Animal \&3 Plant Sciences , 28(1), 244-251.

Das, K. \& Roychoudhury, A. (2014). Reactive oxygen species (ROS) and response of antioxidants as ROS-scavengers during environmental stress in plants. Frontiers in Environmental Science, 2, 53. https://doi.org/10.3389/fenvs.2014.00053.

Del Rio, L.A. (2015). ROS and RNS in plant physiology: An overview.Journal of Experimental Botany , 66(10), 2827-2837. https://doi.org/10.1093/jxb/erv099.

Delignette-Muller, M.L. \& Dutang, C. (2015). Fitdistrplus : An R package for fitting distributions. Journal of Statistical Software, 64(4), 1-34. https://doi.org/10.18637/jss.v064.i04.

Dobson, A., Richardson, J. \& Blossey, B. (2020). Effects of earthworms and white-tailed deer on roots, arbuscular mycorrhizae, and forest seedling performance. Ecology , 101(1), e02903. https://doi.org/10.1002/ecy.2903.

Dolan, R.W., Moore, M.E. \& Stephens, J.D. (2011). Documenting effects of urbanization on flora using herbarium records. Journal of Ecology, 99(4), 1055-1062. https://doi.org/10.1111/j.1365-2745.2011.01820.x.

Donaldson, J.R., Kruger, E.L. \& Lindroth, R.L. (2006). Competition- and resource-mediated tradeoffs between growth and defensive chemistry in trembling aspen (Populus tremuloides ). New Phytologist, 169(3), 561-570. https://doi.org/10.1111/j.1469-8137.2005.01613.x.

Du, B., Jansen, K., Kleiber, A., Eiblmeier, M., Kammerer, B., Ensminger, I., Gessler, A., Rennenberg, H. \& Kreuzwieser, J. (2016). A coastal and an interior douglas fir provenance exhibit different metabolic strategies to deal with drought stress. Tree Physiology, 36(2), 148-163. https://doi.org/10.1093/treephys/tpv105.

Endara, M. \& Coley, P.D. (2011). The resource availability hypothesis revisited: A meta-analysis. Functional Ecology , 25(2), 389-398.

https://doi.org/10.1111/j.1365-2435.2010.01803.x

Estravis-Barcala, M., Mattera, M.G., Soliani, C., Bellora, N., Opgenoorth, L., Heer, K. \& Arana, M.V. (2020). Molecular bases of responses to abiotic stress in trees. Journal of Experimental Botany , 71(13), 3765-3779. https://doi.org/10.1093/jxb/erz532. 
Fernandez, C., Monnier, Y., Santonja, M., Gallet, C., Weston, L.A., Prevosto, B., Saunier, A., Baldy, V. \& Bousquet-Melou, A. (2016). The impact of competition and allelopathy on the trade-off between plant defense and growth in two contrasting tree species. Frontiers in Plant Science, 7, 594. https://doi.org/10.3389/fpls.2016.00594.

Fini, A., Guidi, L., Ferrini, F., Brunetti, C., Di Ferdinando, M., Biricolti, S., Pollastri, S., Calamai, L. \& Tattini, M. (2012). Drought stress has contrasting effects on antioxidant enzymes activity and phenylpropanoid biosynthesis in Fraxinus ornus leaves: An excess light stress affair? Journal of Plant Physiology, 169(10), 929-939. https://doi.org/10.1016/j.jplph.2012.02.014.

Fisichelli, N.A. \& Miller, K.M. (2018). Weeds, worms, and deer: Positive relationships among common forest understory stressors.Biological Invasions , 20(5), 1337-1348. https://doi.org/10.1007/s10530-017-1630-y.

Flory, S.L. \& Clay, K. (2010). Non-native grass invasion suppresses forest succession. Oecologia , 164(4), 1029-1038. https://doi.org/10.1007/s00442-010-1697-y

Frelich, L.E. \& Lorimer, C.G. (1985). Current and predicted long-term effects of deer browsing in hemlock forests in Michigan, USA.Biological Conservation , 34(2), 99-120. https://doi.org/10.1016/00063207(85)90103-X.

Friedman, M.S., Rigsby, C.M. \& Cipollini, D. (2020). Light limitation impacts growth but not constitutive or jasmonate induced defenses relevant to emerald ash borer (Agrilus planipennis ) in white fringetree (Chionanthus virginicus ) or black ash (Fraxinus nigra ). Journal of Chemical Ecology , 46(11-12), 11171130. https://doi.org/10.1007/s10886-020-01223-0.

Gidman, E., Goodacre, R., Emmett, B., Smith, A.R. \& Gwynn-Jones, D. (2003). Investigating plantplant interference by metabolic fingerprinting. Phytochemistry , 63(6), 705. https://doi.org/10.1016/S00319422(03)00288-7.

Gill, S.S. \& Tuteja, N. (2010). Reactive oxygen species and antioxidant machinery in abiotic stress tolerance in crop plants. Plant Physiology and Biochemistry , 48(12), 909-930. https://doi.org/10.1016/j.plaphy.2010.08.016.

Gioria, M. \& Osborne, B.A. (2014). Resource competition in plant invasions: Emerging patterns and research needs. Frontiers in Plant Science, 5, 501. https://doi.org/10.3389/fpls.2014.00501.

Gniazdowska, A. \& Bogatek, R. (2005). Allelopathic interactions between plants: Multi site action of allelochemicals. Acta Physiologiae Plantarum , 27(3), 395-407. https://doi.org/10.1007/s11738-005-0017-3.

Gorchov, D.L., Blossey, B., Averill, K.M., Davalos, A., Heberling, J.M., Jenkins, M.A., Kalisz, S., McShea, W.J., Morrison, J.A., Nuzzo, V., Webster, C.R. \& Waller, D.M. (2021). Differential and interacting impacts of invasive plants and white-tailed deer in eastern U.S. forests. Biological Invasions , 23(9), 2711-2727. https://doi.org/10.1007/s10530-021-02551-2.

Grace, J.B., Anderson, T.M., Olff, H. \& Scheiner, S.M. (2010). On the specification of structural equation models for ecological systems.Ecological Monographs , 80(1), 67-87. https://doi.org/10.1890/09-0464.1.

Grace, J.B. (2006). Structural Equation Modeling and Natural Systems . Cambridge University Press, New York.

Grace, J.B., Youngblood, A. \& Scheiner, S.M. (2009). Structural equation modeling and ecological experiments. Real World Ecology: Large-Scale and Long-Term Case Studies and Methods (eds S. Miao, S. Carstenn \& M. Nungesser), pp. 19-45. Springer, New York.

Griggs, J.A., Rock, J.H., Webster, C.R. \& Jenkins, M.A. (2006). Vegetative legacy of a protected deer herd in Cades Cove, Great Smoky Mountains National Park. Natural Areas Journal , 26(2), 126-136.

https://doi.org/10.3375/0885-8608(2006)26[126:VLOAPD]2.0.CO;2. 
Hahn, P.G. \& Maron, J.L. (2016). A framework for predicting intraspecific variation in plant defense. Trends in Ecology and Evolution, 31(8), 646-656. https://doi.org/10.1016/j.tree.2016.05.007.

Hazrati, H., Fomsgaard, I.S. \& Kudsk, P. (2021). Targeted metabolomics unveil alteration in accumulation and root exudation of flavonoids as a response to interspecific competition. Journal of Plant Interactions , 16(1), 53-63. https://doi.org/10.1080/17429145.2021.1881176.

Herms, D.A. \& Mattson, W.J. (1992). The dilemma of plants: To grow or defend. Quarterly Review of Biology , 67(3), 283-335. https://doi.org/10.1086/417659.

Hopewell Valley Deer Management Task Force (2014). Report, https://www.hopewelltwp.org/ArchiveCenter/ViewFile/Item/237.

Horsley, S.B., Stout, S.L. \& deCalesta, D.S. (2003). White-tailed deer impact on the vegetation dynamics of a northern hardwood forest.Ecological Applications , 13(1), 98-118. https://doi.org/10.1890/10510761(2003)013[0098:WTDIOT]2.0.CO;2.

Huberty, M., Choi, Y.H., Heinen, R. \& Bezemer, T.M. (2020). Above-ground plant metabolomic responses to plant-soil feedbacks and herbivory. Journal of Ecology, 108(4), 1703-1712. https://doi.org/10.1111/13652745.13394 .

Hunter, J.C. \& Mattice, J.A. (2002). The spread of woody exotics into the forests of a northeastern landscape, 1938-1999. Journal of the Torrey Botanical Society, 129(3), 220-227. https://doi.org/10.2307/3088772.

Imaji, A. \& Seiwa, K. (2010). Carbon allocation to defense, storage, and growth in seedlings of two temperate broad-leaved tree species.Oecologia , 162(2), 273-281. https://doi.org/10.1007/s00442-009-1453-3.

Kalisz, S., Kivlin, S.N. \& Bialic-Murphy Lalasia (2021). Allelopathy is pervasive in invasive plants. Biological Invasions , 23(2), 367-371.

https://doi-org.ezproxy.tcnj.edu/10.1007/s10530-020-02383-6

Koh, S., Bazely, D.R., Tanentzap, A.J., Voigt, D.R. \& Da Silva, E. (2010). Trillium grandiflorum height is an indicator of white-tailed deer density at local and regional scales. Forest Ecology and Management, 259(8), 1472-1479. https://doi.org/10.1016/j.foreco.2010.01.021

Krueger, L.M., Peterson, C.J., Royo, A. \& Carson, W.P. (2009). Evaluating relationships among tree growth rate, shade tolerance, and browse tolerance following disturbance in an eastern deciduous forest. Canadian Journal of Forest Research , 39(12), 2460-2469. https://doi.org/10.1139/X09-155.

Lamb, E.G. \& Cahill Jr, J.F. (2008). When competition does not matter: Grassland diversity and community composition. The American Naturalist, 171(6), 777-787. https://doi.org/10.1086/587528.

Lefcheck, J.S. \& Freckleton, R. (2016). piecewiseSEM: Piecewise structural equation modelling in $\mathrm{R}$ for ecology, evolution, and systematics. Methods in Ecology and Evolution, 7(5), 573-579. https://doi.org/10.1111/2041-210X.12512.

Levine, J.M., Vila, M., D’Antonio, C.M., Dukes, J.S., Grigulis, K. \& Lavorel, S. (2003). Mechanisms underlying the impacts of exotic plant invasions. Proceedings of the Royal Society of London, Series B: Biological Sciences , 270(1517), 775-781. https://doi.org/10.1098/rspb.2003.2327.

Liang, S.Y. \& Seagle, S.W. (2002). Browsing and microhabitat effects on riparian forest woody seedling demography. Ecology, 83(1), 212-227. https://doi.org/10.1890/0012-9658(2002)083[0212:BAMEOR]2.0.CO;2.

Lindroth, R.L., Donaldson, J.R., Stevens, M.T. \& Gusse, A.C. (2007). Browse quality in quaking aspen (Populus tremuloides ): Effects of genotype, nutrients, defoliation, and coppicing. Journal of Chemical Ecology , 33(5), 1049-1064. https://doi.org/10.1007/s10886-007-9281-6.

Massad, T.J., Martins de Moraes, M., Philbin, C., Oliveira, C., Cebrian Torrejon, G., Fumiko Yamaguchi, L., Jeffrey, C.S., Dyer, L.A., Richards, L.A. \& Kato, M.J. (2017). Similarity in volatile com- 
munities leads to increased herbivory and greater tropical forest diversity.Ecology , 98(7), 1750-1756. https://doi.org/10.1002/ecy.1875.

McGarvey, J.C., Bourg, N.A., Thompson, J.R., McShea, W.J. \& Shen, X. (2013). Effects of twenty years of deer exclusion on woody vegetation at three life-history stages in a Mid-Atlantic temperate deciduous forest.Northeastern Naturalist , 20(3), 451-468. https://doi.org/10.1656/045.020.0301.

Miranda-Apodaca, J., Mena-Petite, A., Lacuesta, M., Munoz-Rueda, A. \& Perez-Lopez, U. (2020). A physiological approach to study the competition ability of the grassland species Trifolium pratenseand Agrostis capillaris . Journal of Plant Physiology, 254, 153284. https://doi.org/10.1016/j.jplph.2020.153284.

Morrison, J.A. \& Brown, L. (2004). Effect of herbivore exclosure caging on the invasive plant Alliaria petiolata in three southeastern New York forests. Bartonia, 62, 25-43.

Morrison, J.A., Fertitta, M., Zymaris, C., diBartolo, A. \& Akparanta, C. (2021). Deer and invasive plants in suburban forests: Assessing variation in deer pressure and herbivory. Ecoscience, https://doi.org/10.1080/11956860.2021.1958535.

Morse, N.B., Pellissier, P.A., Cianciola, E.N., Brereton, R.L., Sullivan, M.M., Shonka, N.K., Wheeler, T.B. \& McDowell, W.H. (2014). Novel ecosystems in the anthropocene: A revision of the novel ecosystem concept for pragmatic applications. Ecology and Society, 19(2), 12. https://doi.org/10.5751/ES-06192-190212.

Nosko, P. \& Embury, K. (2018). Induction and persistence of allelochemicals in the foliage of balsam fir seedlings following simulated browsing. Plant Ecology, 219(6), 611-619. https://doi.org/10.1007/s11258018-0821-7.

Nyland, R.D., Bashant, A.L., Bohn, K.K. \& Verostek, J.M. (2006). Interference to hardwood regeneration in northeastern North America: Ecological characteristics of American beech, striped maple, and hobblebush. Northern Journal of Applied Forestry, 23(1), 53-61. https://doi.org/10.1093/njaf/23.1.53.

Ohse, B., Hammerbacher, A., Seele, C., Meldau, S., Reichelt, M., Ortmann, S. \& Wirth, C. (2017). Salivary cues: Simulated roe deer browsing induces systemic changes in phytohormones and defence chemistry in wild-grown maple and beech saplings. Functional Ecology , 31(2), 340-349. https://doi.org/10.1111/13652435.12717 .

Orr, J.A., Vinebrooke, R.D., Jackson, M.C., Kroeker, K.J., Kordas, R.L., Mantyka-Pringle, C., Van den Brink, Paul J, De Laender, F., Stoks, R. \& Holmstrup, M. (2020). Towards a unified study of multiple stressors: Divisions and common goals across research disciplines.Proceedings of the Royal Society B , 287(1926), 20200421. https://doi.org/10.1098/rspb.2020.0421.

Oswalt, C.M., Oswalt, S.N. \& Clatterbuck, W.K. (2007). Effects ofMicrostegium vimineum (trin.) A. Camus on native woody species density and diversity in a productive mixed-hardwood forest in Tennessee. Forest Ecology and Management, 242(2-3), 727-732. https://doi.org/10.1016/j.foreco.2007.02.008.

Ozsoy, N., Can, A., Yanardag, R. \& Akev, N. (2008). Antioxidant activity of Smilax excelsa L. leaf extracts. Food Chemistry, 110(3), 571-583. https://doi.org/10.1016/j.foodchem.2008.02.037.

Peters, K., Worrich, A., Weinhold, A., Alka, O., Balcke, G., Birkemeyer, C., Bruelheide, H., Calf, O.W., Dietz, S., Duhrkop, K., Gaquerel, E., Heinig, U., Kucklich, M., Macel, M., Muller, C., Poeschl, Y., Pohnert, G., Ristok, C., Rodriguez, V.M., Ruttkies, C. et al. (2018). Current challenges in plant eco-metabolomics. International Journal of Molecular Sciences , 19(5), 1385. https://doi.org/10.3390/ijms19051385.

Peterson, R.A. \& Cavanaugh, J.E. (2020). Ordered quantile normalization: A semiparametric transformation built for the cross-validation era. Journal of Applied Statistics , 47(13-15), 2312-2327. https://doi.org/10.1080/02664763.2019.1630372.

Pickering, C.M., Hill, W., Newsome, D. \& Leung, Y. (2010). Comparing hiking, mountain biking and horse riding impacts on vegetation and soils in Australia and the United States of America. Journal of 
Environmental Management, 91(3), 551-562. https://doi.org/10.1016/j.jenvman.2009.09.025.

Pierson, T.G. \& deCalesta, D.S. (2015). Methodology for estimating deer browsing impact. Human-Wildlife Interactions , 9(1), 67. https://doi.org/10.26077/rbw0-bn49.

Potapov, E., Bedford, A., Bryntesson, F., Cooper, S., Nyholm, B. \& Robertson, D. (2014). White-tailed deer (Odocoileus virginianus) suburban habitat use along disturbance gradients. American Midland Naturalist, 171(1), 128-138. https://doi.org/10.1674/0003-0031-171.1.128.

R Core Team (2020). R: A language and environment for statistical computing, https://www.R-project.org/.

Reddy, A.R., Chaitanya, K.V. \& Vivekanandan, M. (2004). Drought-induced responses of photosynthesis and antioxidant metabolism in higher plants.Journal of Plant Physiology , 161(11), 1189-1202. https://doi.org/10.1016/j.jplph.2004.01.013.

Rivas-Ubach, A., Gargallo-garriga, A., Sardans, J., Oravec, M., Mateu-Castell, L., Perez-Trujillo, M., Parella, T., Ogaya, R., Urban, O. \& Penuelas, J. (2014). Drought enhances folivory by shifting foliar metabolomes in Quercus ilex trees. New Phytologist , 202(3), 11-21. https://doi.org/10.1111/nph.12687.

Rockenbach, A.P., Rizzardi, M.A. \& Hause, B. (2020). Competition at the soybean V6 stage affects root morphology and biochemical composition.Plant Biology ,22(2), 252-258. https://doi.org/10.1111/plb.13070.

Russell, F.L., Zippin, D.B. \& Fowler, N.L. (2001). Effects of white-tailed deer (Odocoileus virginianus ) on plants, plant populations and communities: A review. American Midland Naturalist , 146(1), 1-26.

https://doi.org/10.1674/0003-0031(2001)146[0001:EOWTDO]2.0.CO;2.

Ruxton, G.D. \& Beauchamp, G. (2008). Time for some a priori thinking about post hoc testing. Behavioral Ecology , 19(3), 690-693. https://doi.org/10.1093/beheco/arn020.

Ryan, K.G., Swinny, E.E., Winefield, C. \& Markham, K.R. (2001). Flavonoids and UV photoprotection in Arabidopsis mutants.Zeitschrift Fur Naturforschung, 56c, 745-754. https://doi.org/10.1515/znc-2001-91013.

Sampedro, L., Moreira, X. \& Zas, R. (2011). Costs of constitutive and herbivore-induced chemical defences in pine trees emerge only under low nutrient availability. Journal of Ecology , 99(3), 818-827.

SAS Institute Inc. (2015). SAS/STAT(r) 14.1 User's Guide. SAS Institute, Inc., Cary, NC.

Schramm, J.W. \& Ehrenfeld, J.G. (2012). Patterns of patch colonization and expansion in the non-native annual grass Microstegium vimineum (Poaceae). Rhodora , 114(957), 1-20. https://doi.org/10.3119/00354902-114.957.1.

Sedio, B.E., Rojas Echeverri, J.C., Boya P, C.A. \& Wright, S.J. (2017). Sources of variation in foliar secondary chemistry in a tropical forest tree community. Ecology , 98(3), 616-623. http://dx.doi.org/10.1002/ecy.1689.

Sedio, B.E., Devaney, J.L., Pullen, J., Parker, G.G., Wright, S.J. \& Parker, J.D. (2020). Chemical novelty facilitates herbivore resistance and biological invasions in some introduced plant species. Ecology and Evolution, 10(16), 8770-8792. https://doi.org/10.1002/ece3.6575.

Shams Ardekani, M.R., Hajimahmoodi, M., Oveisi, M.R., Sadeghi, N., Jannat, B., Ranjbar, A.M., Gholam, N. \& Moridi, T. (2011). Comparative antioxidant activity and total flavonoid content of Persian pomegranate (Punica granatum L.) cultivars. Iranian Journal of Pharmaceutical Research, 10(3), 519-524. https://doi.org/10.1016/j.arabjc.2013.10.011.

Skurski, T.C., Rew, L.J. \& Maxwell, B.D. (2014). Mechanisms underlying nonindigenous plant impacts: A review of recent experimental research.Invasive Plant Science and Management, 7(3), 432-444. https://doi.org/10.1614/IPSM-D-13-00099.1. 
Sokal, R.R. \& Rohlf, F.J. (1981). Biometry, 2nd edn. W.H. Freeman and Company, New York.

Steppuhn, A. \& Baldwin, I.T. (2008). Induced defenses and the cost-benefit paradigm. Induced Plant Resistance to Herbivory (ed A. Schaller), pp. 61-83. Springer.

Sudnick, M., Brodie, B.S. \& Williams, K.A. (2021). Nature versus nurture: Structural equation modeling indicates that parental care does not mitigate consequences of poor environmental conditions in eastern bluebirds (Sialia sialis ). Ecology and Evolution, 11(21), 15237-15248. https://doi.org/10.1002/ece3.8207.

Swihart, R.K. \& Bryant, J.P. (2001). Importance of biogeography and ontogeny of woody plants in winter herbivory by mammals. Journal of Mammalogy , 82(1), 1-21. https://doi.org/10.1644/15451542(2001)0822.0.CO;2.

Urbanek, R.E. \& Nielsen, C.K. (2013). Influence of landscape factors on density of suburban white-tailed deer. Landscape and Urban Planning , 114(0), 28-36. https://doiorg.ezproxy.tcnj.edu/10.1016/j.landurbplan.2013.02.006.

Valkama, E., Koricheva, J., Ossipov, V., Ossipova, S., Haukioja, E. \& Pihlaja, K. (2005). Delayed induced responses of birch glandular trichomes and leaf surface lipophilic compounds to mechanical defoliation and simulated winter browsing. Oecologia , 146(3), 385-393. https://doi.org/10.1007/s00442-005-0216-z.

Vila, B., Vourc'h, G., Gillon, D., Martin, J. \& Guibal, F. (2002). Is escaping deer browse just a matter of time in Picea sitchensis ? A chemical and dendroecological approach. Trees , 16(7), 488-496. http://dx.doi.org/10.1007/s00468-002-0191-5.

Vila, M., Espinar, J.L., Hejda, M., Hulme, P.E., Jarošík, V., Maron, J.L., Pergl, J., Schaffner, U., Sun, Y. \& Pyšek, P. (2011). Ecological impacts of invasive alien plants: A meta-analysis of their effects on species, communities and ecosystems. Ecology Letters , 14(7), 702-708. https://doi.org/10.1111/j.14610248.2011.01628.x.

Viola, D.V., Mordecai, E.A., Jaramillo, A.G., Sistla, S.A., Albertson, L.K., Gosnell, J.S., Cardinale, B.J. \& Levine, J.M. (2010). Competition-defense tradeoffs and the maintenance of plant diversity.Proceedings of the National Academy of Sciences of the United States of America , 107(40), 17217. https://doi.org/10.1073/pnas.1007745107.

Vuleta, A., Manitašević Jovanović, S. \& Tucić, B. (2015). How do plants cope with oxidative stress in nature? A study on the dwarf bearded iris (Iris pumila ). Acta Physiologiae Plantarum , 37(1), 1-12. https://doi.org/10.1007/s11738-014-1711-9.

Waite, T.A. \& Campbell, L.G. (2006). Controlling the false discovery rate and increasing statistical power in ecological studies.Écoscience , 13(4), 439-442. https://doi.org/10.2980/11956860(2006)13[439:CTFDRA]2.0.CO;2.

Walters, M.B., Farinosi, E.J. \& Willis, J.L. (2020). Deer browsing and shrub competition set sapling recruitment height and interact with light to shape recruitment niches for temperate forest tree species. Forest Ecology and Management , 467, 118134. https://doi.org/10.1016/j.foreco.2020.118134.

Williams, S.C., Denicola, A.J., Almendinger, T. \& Maddock, J. (2013). Evaluation of organized hunting as a management technique for overabundant white-tailed deer in suburban landscapes. Wildlife Society Bulletin , 37(1), 137-145. https://doi.org/10.1002/wsb.236.

Wu, J. \& Baldwin, I.T. (2009). Herbivory-induced signalling in plants: Perception and action. Plant, Cell E Environment , 32(9), 1161-1174. https://doi.org/10.1111/j.1365-3040.2009.01943.x.

Table 1. Deer pressure-related forest characteristics. All variables except hunting were measured in 32-40 $16 \mathrm{~m}^{2}$ plots per forest. Values for shrub cover and species richness are the mean and SE. All data were from 2012, except percent browse was for species that were browsed in 2015 (with total sampled plants in 
parentheses). The canopy importance values for red + black oak are shown in parentheses, followed by the ranking of their importance value (IV) in that forest.

\begin{tabular}{|c|c|c|c|c|c|}
\hline Forest & $\begin{array}{l}\text { Years of } \\
\text { hunting }^{1}\end{array}$ & $\begin{array}{l}\text { Percent native } \\
\text { shrub cover }\end{array}$ & $\begin{array}{l}\text { Herb layer } \\
\text { native species } \\
\text { richness }^{2}\end{array}$ & $\begin{array}{l}\text { \# Plots with } \\
\text { red/black oak } \\
\text { juveniles in } \\
\text { spring, fall }\end{array}$ & $\begin{array}{l}\text { Percent } \\
\text { browse index }\end{array}$ \\
\hline Baldpate (BAL) & 12 & $56(4)$ & $22(0.9)$ & $\begin{array}{l}\text { 18, } 17(\mathrm{IV}=33.1 \\
\# 3)\end{array}$ & $\begin{array}{l}0.39 \% \text { (out of } \\
520 \text { ) }\end{array}$ \\
\hline Nayfield (NAY) & 5 & $27(4)$ & $13(0.5)$ & $\begin{array}{l}18,22(\mathrm{IV}=84.7 \\
\# 2)\end{array}$ & $\begin{array}{l}2.3 \% \text { (out of } \\
442 \text { ) }\end{array}$ \\
\hline $\begin{array}{l}\text { Herronton } \\
\text { (HER) }\end{array}$ & 17 & $15(3)$ & $21(0.8)$ & $\begin{array}{l}9,11(\mathrm{IV}=32.4 \\
\# 5)\end{array}$ & $\begin{array}{l}2.1 \% \text { (out of } \\
280 \text { ) }\end{array}$ \\
\hline Eames (EAM) & 5 & $6.2(3)$ & $7.9(0.3)$ & $\begin{array}{l}6,0(\mathrm{IV}=16.0 \\
\# 5)\end{array}$ & $\begin{array}{l}6.3 \% \text { (out of } \\
160)\end{array}$ \\
\hline Curlis (CUR) & 0 & $2.5(0.9)$ & $6.8(0.4)$ & $\begin{array}{l}4,5(\mathrm{IV}=94.0 \\
\# 2)\end{array}$ & $10 \%$ (out of 228 ) \\
\hline Rosedale (ROS) & 0 & $0.55(0.4)$ & $8.7(0.4)$ & $\begin{array}{l}2,1 \\
\# 4)\end{array}(\mathrm{IV}=29.8$ & $11 \%$ (out of 186$)$ \\
\hline
\end{tabular}

${ }^{1}$ Hunting history was provided by Hopewell Valley Friends of Open Space and the Mercer County Parks Department, the owners and managers of these natural areas.

${ }^{2}$ Native shrub cover and herb layer native species richness decrease with deer overabundance (Rawinski 2008). Shrub cover was measured with a 'forest secchi' method (from Michael Van Clef, Hopewell Valley Friends of Open Space). It quantifies the percent vertical foliage cover of native woody plants in the deer browse zone, $0.4 \mathrm{~m}-1.4 \mathrm{~m}$ from the ground (Pierson \& deCalesta 2015), by a researcher observing from across the plot a $1 \mathrm{~m}^{2}$ board that was divided into a $4 \mathrm{x} 4 \mathrm{grid}$, and counting the percentage of grid squares intercepted by native woody plants. This was done in two perpindicular directions and the values were averaged. Native species richness was from a spring herb layer census, using the census method described in the paper; values shown are for the number of species in the $16 \mathrm{~m}^{2}$ plots.

${ }^{3}$ Quercus rubra and/or Q. velutina (red and black oak) were the only preferred deer food species (Wakeland \& Swihart 2009) that also are common seed-source canopy trees in each of this study's forests. Quercus presence was from spring and fall censuses. Canopy tree importance values for Q. rubra plus $Q$. velutina were obtained with standard procedures (Brower et al. 1990).

4 The presence of tell-tale shredded twig tips indicated deer browse (Pierson \& deCalesta 2015). The browse index for each forest consisted of the proportion of browsed individuals in unfenced plots of five native species that were browsed by deer and sufficiently common in the forests' understories to use for comparison between forests: Carya spp., Fagus grandifolia,Fraxinus pennsylvanica, Acer rubrum, and Rubus allegheniensis .

Table 2. Mixed model results for the effects of fencing treatment, Microstegium vimineum (MIVI) cover, and interactions on foliar antioxidant capacity (A), phenolics concentration (B), and flavonoid concentration (C) in juveniles of the tree species Fraxinus pennsylvanica and Fagus grandifolia growing in forests of central New Jersey, USA.

\begin{tabular}{lllllll}
\hline $\begin{array}{l}\text { Source of } \\
\text { variation }\end{array}$ & $\begin{array}{l}\text { F. } \\
\text { pennsylvanica }\end{array}$ & $\begin{array}{l}\text { F. } \\
\text { pennsylvanica }\end{array}$ & $\begin{array}{l}\text { F. } \\
\text { pennsylvanica }\end{array}$ & $\begin{array}{l}\text { F. } \\
\text { grandifolia }\end{array}$ & $\begin{array}{l}\text { F. } \\
\text { grandifolia }\end{array}$ & $\begin{array}{l}\text { F. } \\
\text { grandifolia }\end{array}$ \\
\hline $\begin{array}{l}\text { DF (num, } \\
\text { den) }\end{array}$ & F & P & $\begin{array}{l}\text { DF (num, } \\
\text { den) }\end{array}$ & F & P
\end{tabular}




\begin{tabular}{lllllll}
\hline $\begin{array}{l}\text { Source of } \\
\text { variation }\end{array}$ & $\begin{array}{l}\text { F. } \\
\text { pennsylvanica }\end{array}$ & $\begin{array}{l}\text { F. } \\
\text { pennsylvanica }\end{array}$ & $\begin{array}{l}\text { F. } \\
\text { pennsylvanica }\end{array}$ & $\begin{array}{l}\text { F. } \\
\text { grandifolia }\end{array}$ & $\begin{array}{l}\text { F. } \\
\text { grandifolia }\end{array}$ & $\begin{array}{l}\text { F. } \\
\text { grandifolia }\end{array}$ \\
\hline $\begin{array}{l}\text { A) } \\
\text { ANTIOXI- }\end{array}$ & & & & & \\
DANTS & 1,140 & 5.7 & 0.02 & 1,105 & 0.04 & 0.9 \\
$\begin{array}{l}\text { fencing } \\
\text { MIVI cover }\end{array}$ & 3,140 & 2.1 & 0.10 & 3,105 & 2.8 & 0.05 \\
$\begin{array}{l}\text { category } \\
\text { fencing x }\end{array}$ & 3,140 & 0.40 & 0.8 & 3,105 & 0.3 & 0.8 \\
$\begin{array}{l}\text { MIVI cover } \\
\text { B) PHE- }\end{array}$ & & & & & \\
$\begin{array}{l}\text { NOLICS } \\
\text { fencing }\end{array}$ & 1,144 & 6.4 & & & & \\
$\begin{array}{l}\text { MIVI cover } \\
\text { category }\end{array}$ & 3,144 & 1.0 & 0.01 & 1,105 & 0.46 & 0.5 \\
fencing x & 3,144 & 1.2 & 0.4 & 3,105 & 1.9 & 0.14 \\
$\begin{array}{l}\text { MIVI cover } \\
\text { C) }\end{array}$ & & 0.3 & 3,105 & 1.4 & 0.3 \\
FLAVONOIDS & & & & & \\
fencing & 1,144 & 3.8 & & & & \\
$\begin{array}{l}\text { MIVI cover } \\
\text { category }\end{array}$ & 3,144 & 1.3 & 0.05 & 1,97 & 0.11 & 0.7 \\
fencing x & 3,144 & 1.0 & 0.3 & 3,97 & 2.3 & 0.08 \\
MIVI cover & & & & & & \\
\hline
\end{tabular}

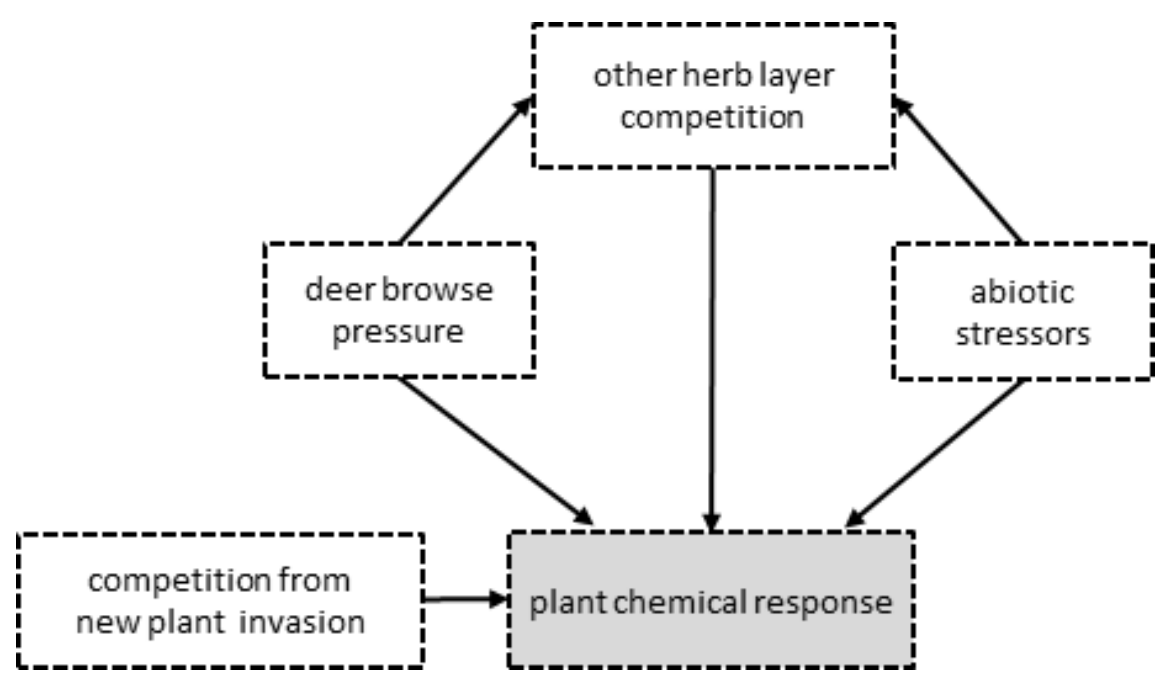

Figure 1. Structural equation meta-model (SEMM), a system-wide hypothesis of theoretical, interconnected drivers of woody plant chemistry in suburban forests. 


\section{A. SE measurement model for Fraxinus pennsylvanica}

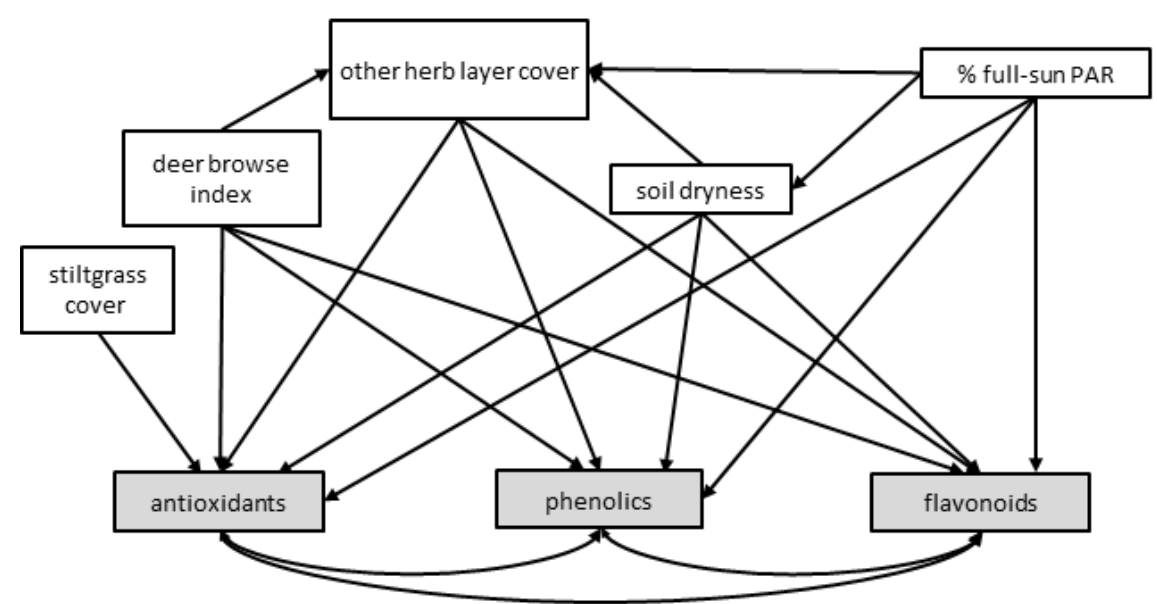

B. SE measurement model for Fagus grandifolia

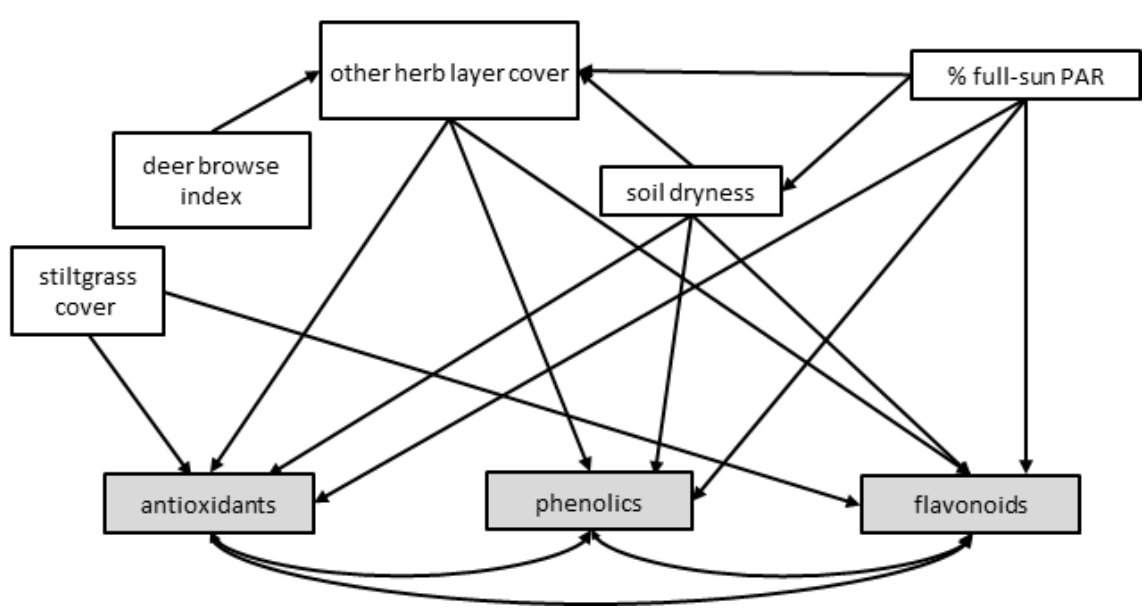

Figure 2. Initial structural equation measurement model, based on the SEMM of Fig. 1 and guided by results from the univariate analyses. 


\section{Fraxinus pennsylvanica}
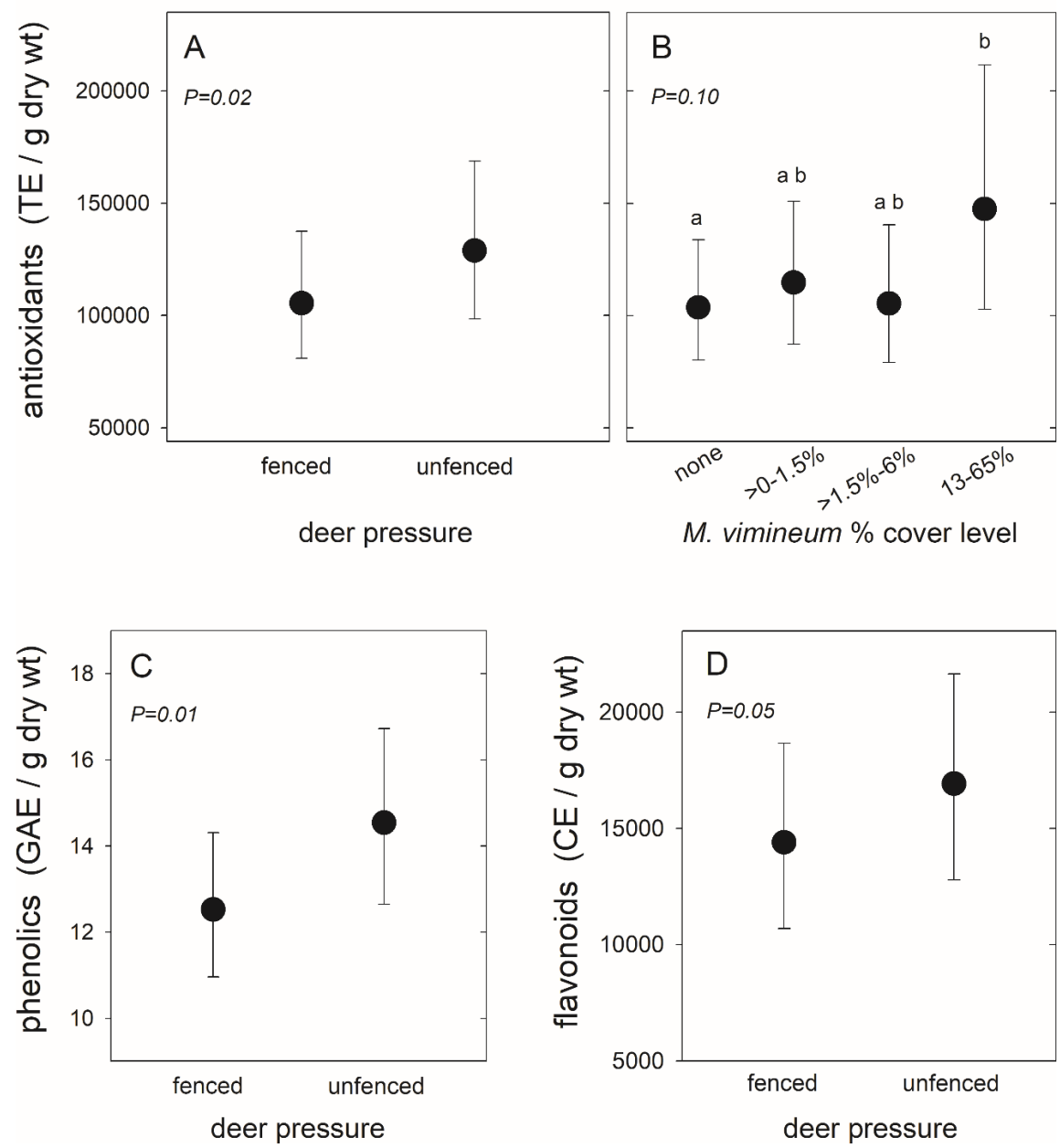

Figure 3. Total antioxidants (A), phenolics (B, C) and flavonoids (D) in leaves of Fraxinus pennsylvanica juveniles in central New Jersey, USA forests. Plants grew in fenced or unfenced plots (A, C, D) and with four levels of Microstegium vimineum cover (B). Graphs show least-squares means $+95 \%$ CL, backtransformed from $\log _{10}$ for antioxidants and phenolics and from square roots for flavonoids. $\mathrm{N}$ for each mean, from right to left: A) 77, 75; B) 84, 35, 24, 9; C and D) 79, 77. Means labeled with different letters in B were different only at the $\mathrm{P}=0.09$ level, based on adjustment for six multiple comparisons with the Tukey-Kramer method. 
Fagus grandifolia
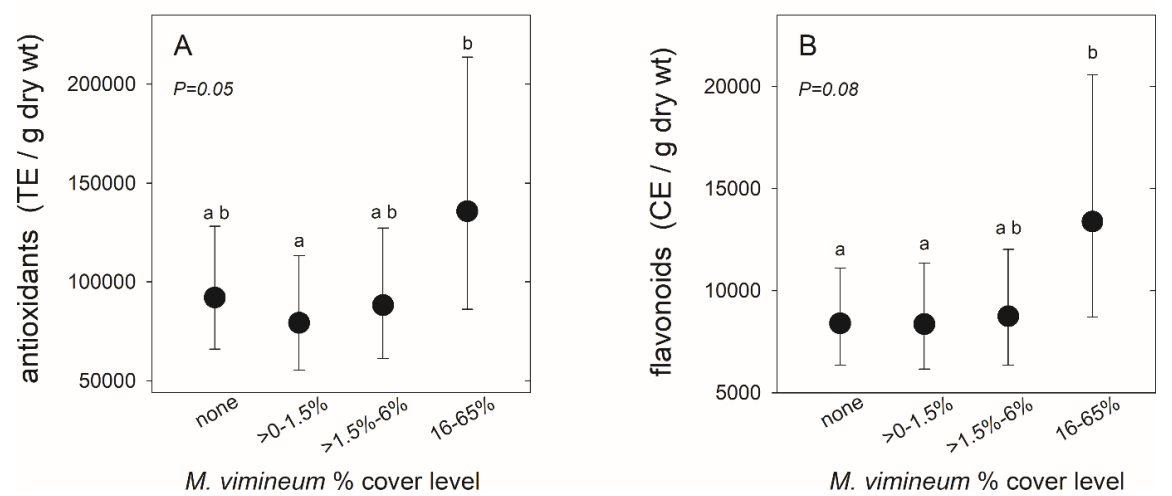

Figure 4. Total antioxidants (A) and flavonoids (B) in leaves of Fagus grandifolia juveniles in central New Jersey, USA forests growing with four levels of Microstegium vimineum cover. Graphs show least-squares means $+95 \% \mathrm{CL}$, backtransformed from $\log _{10}$. $\mathrm{N}$ for each mean, from right to left: A) $61,25,22,9$; B) 60 , 13, 19, 7. Means labeled with different letters in $\mathrm{A}$ were different at $\mathrm{P}=0.03$ and in $\mathrm{B}$ they were different only at $\mathrm{P}=0.06$ (none vs. $16-65 \%$ ) and $\mathrm{P}=0.07$ ( $>0-1,5 \%$ vs. 16-65\%) level, based on adjustment for six multiple comparisons with the Tukey-Kramer method.

A. Fraxinus pennsylvanica

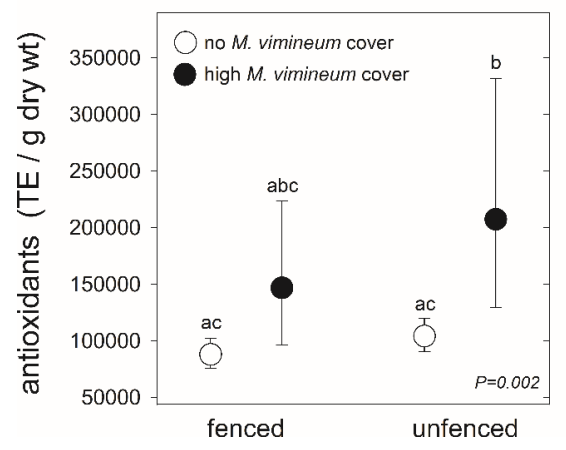

B. Fagus grandifolia

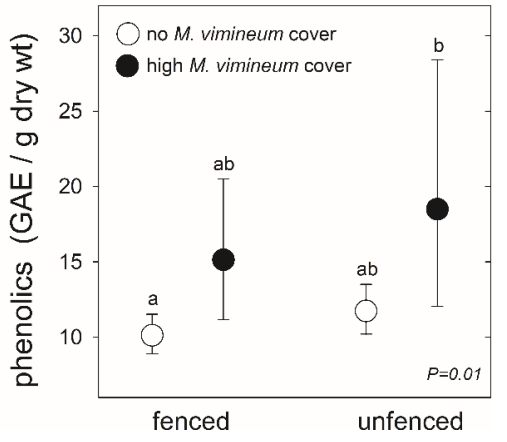

Figure 5. Total Fraxinus pennsylvanica antioxidants (A) andFagus grandifolia phenolics (B) in leaves of juveniles in central New Jersey, USA forests growing in fenced or unfenced plots and with noMicrostegium vimineum cover or high cover, defined as $12-65 \%$. Graphs show least-squares means $+95 \%$ CL, backtransformed from $\log _{10}$. $\mathrm{N}$ for each mean, from right to left: A) 39, 4, 49, 4; B)33, 6, 28, 3. Based on adjustment for six multiple comparisons with the Tukey-Kramer method, means labeled in A with different letters were different at $\mathrm{P}=0.005$ (fenced/no cover vs. unfenced/high cover) and $\mathrm{P}=.03$ (unfenced/no cover vs. unfenced/high cover). In $\mathrm{B}$, they were different at $\mathrm{P}=0.04$ (fenced/no cover vs. unfenced/high cover). 


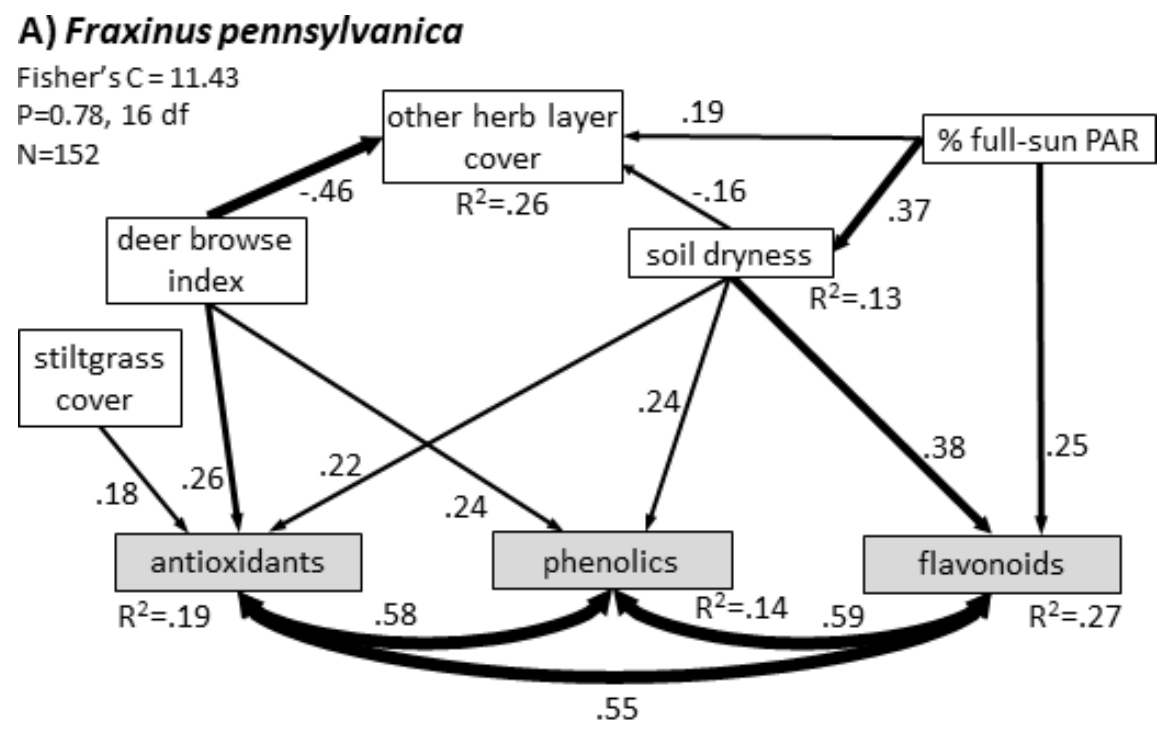

\section{B) Fagus grandifolia}

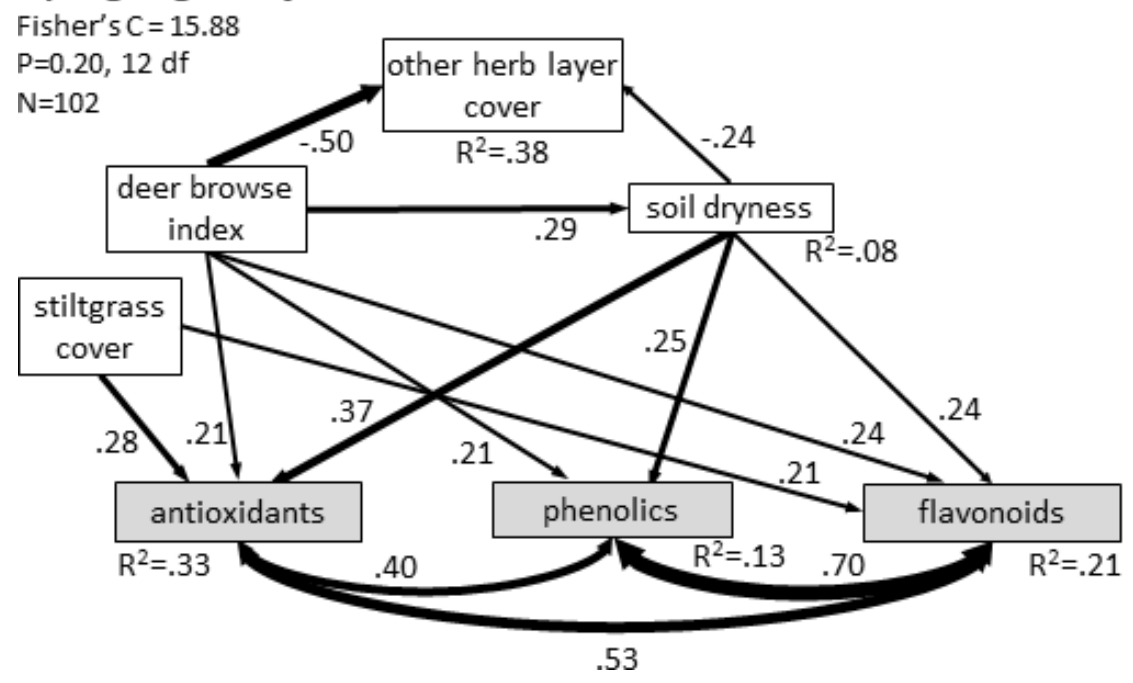

Figure 6. Fitted structural equation models of drivers of foliar plant secondary chemistry in juveniles of the trees Fraxinus pennsylvanica and Fagus grandifolia, growing in suburban forests of central New Jersey, USA. Path thickness is proportional to the values of the standardized path coefficient labels. All paths are significant at $\mathrm{P}<0.05$.

\section{DATA ACCESSIBILITY STATEMENT}

Data used for this paper will be available from the Dryad Digital Repository.

\section{COMPETING INTERESTS STATEMENT}

There are no competing interests.

\section{AUTHORS' CONTRIBUTIONS}

Morrison and Roche formulated and designed the study, planned the statistical analyses, interpreted the results, outlined the introduction and discussion, edited all drafts, and responded to review comments. 
Morrison was responsible for plot installation and treatments, collection of leaf samples and field data, leading the statistical analysis, and writing most sections of the paper. Roche participated in statistical analysis and interpretation and wrote sections of the paper. Veatch-Blohm conducted the chemical analyses and wrote the methods for that part. All authors gave final approval for publication.

\section{ACKNOWLEDGEMENTS}

This research was supported by the National Science Foundation (USA; NSF-DEB 1257833; PI, JA Morrison) and Academic Affairs at The College of New Jersey, for reassigned time to Morrison through the Support for Scholarly Activity committee and the Barbara Meyers Pelson ' 59 Chair in Faculty-Student Engagement. Thanks to many TCNJ undergraduate students who contributed to this study, especially the summer/fall 2015 crew: Scott Eckert Ryan Goolic, Marisa Grillo, Elizabeth Matthews, Cindy Timko, Gio Tomat-Kelly Mitchell Vaughn, Jen Wells, Ryan Goolic. Thanks also to an associate editor and two anonymous reviewers for valuable critiques, which greatly improved the manuscript. 